Journal of Financial Economics 00 (0000) 000-000

\title{
Who makes acquisitions? CEO overconfidence and the market's reaction
}

\author{
Ulrike Malmendier ${ }^{\mathrm{a}}$, Geoffrey Tate ${ }^{\mathrm{b}^{*}}$ \\ ${ }^{a}$ University of California, Berkeley, Berkeley, CA, 94720, USA \\ ${ }^{b}$ University of California at Los Angeles, Los Angeles, CA, 90095, USA
}

Received 22 May 2006; received in revised form 18 June 2007;

accepted 17 July 2007

\begin{abstract}
Does CEO overconfidence help to explain merger decisions? Overconfident CEOs overestimate their ability to generate returns. As a result, they overpay for target companies and undertake value-destroying mergers. The effects are strongest if they have access to internal financing. We test these predictions using two proxies for overconfidence: CEOs' personal overinvestment in their company and their press portrayal. We find that the odds of making an acquisition are $65 \%$ higher if the CEO is classified as overconfident. The effect is largest if the merger is diversifying and does not require external financing. The market reaction at merger announcement (-90 basis points) is significantly more negative than for non-overconfident CEOs (-12 basis points). We consider alternative interpretations including inside information, signaling, and risk tolerance.

JEL classifications: D80; G14; G32; G34
\end{abstract}

Keywords: Mergers and Acquisitions, Returns to Mergers, Overconfidence, Hubris, Managerial Biases

We are indebted to Brian Hall, Kenneth Froot, Mark Mitchell and David Yermack for providing us with essential parts of the data. We are very grateful to Jeremy Stein and Andrei Shleifer for their invaluable support and comments. We also would like to thank Gary Chamberlain, David Laibson and various participants in seminars at Harvard University, Stanford University, University of Chicago, Northwestern University, Wharton, Duke University, University of Illinois, Emory University, Carnegie Mellon University, INSEAD and Humboldt University of Berlin for helpful comments. Becky Brunson, Justin Fernandez, Jared Katseff, Camelia Kuhnen, and Felix Momsen provided excellent research assistance. The authors acknowledge support from the Russell Sage Foundation, the Division of Research of the Harvard Business School (Malmendier) and the Center for Basic Research in the Social Sciences at Harvard (Tate).

*Corresponding author contact information: E-mail address: geoff.tate@anderson.ucla.edu

0000-000X/00/ \$ see front matter @ 0 0000Published by Elsevier Science B.V. All rights reserved 


\section{Introduction}

"Many managements apparently were overexposed in impressionable childhood years to the story in which the imprisoned handsome prince is released from a toad's body by a kiss from a beautiful princess. Consequently, they are certain their managerial kiss will do wonders for the profitability of Company T[arget]...We've observed many kisses but very few miracles. Nevertheless, many managerial princesses remain serenely confident about the future potency of their kisses-even after their corporate backyards are kneedeep in unresponsive toads."

-Warren Buffet, Berkshire Hathaway Inc. Annual Report, $1981^{1}$

U.S. firms spent more than $\$ 3.4$ trillion on over 12,000 mergers during the last two decades. If chief executive officers (CEOs) act in the interest of their shareholders, these mergers should have increased shareholder wealth. Yet, acquiring shareholders lost over $\$ 220$ billion at the announcement of merger bids from 1980 to 2001 (Moeller, Schlingemann, and Stulz, 2005). While the joint effect of mergers on acquiror and target value may be positive, acquiring shareholders appear to be on the losing end. ${ }^{2}$ In this paper, we ask whether CEO overconfidence helps to explain the losses of acquirors.

Overconfidence has long had popular appeal as an explanation for failed mergers. ${ }^{3}$ Roll (1986) first formalized the notion, linking takeover contests to the winner's curse. The implications of overconfidence for mergers, however, are more subtle than mere overbidding. Overconfident CEOs also overestimate the returns they generate internally and believe outside investors undervalue their companies. As a result, they are reluctant to raise external finance and may forgo mergers if external capital is required. The

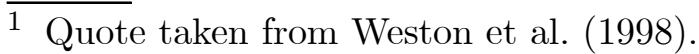

2 Andrade et al. (2001) find average stock price reactions of -0.4 and $-1.0 \%$ over a three-day window for acquirors during the 1980s and 1990s; see also Dodd (1980), Firth (1980), and Ruback and Mikkelson (1984). Targets may gain from merger bids; see Asquith (1983) and Bradley et al. (1983). Jensen and Ruback (1983) and Roll (1986) survey earlier studies.

3 Recent business press articles include CFO Magazine, June 1, 2004 ("Avoiding Decision Traps"); US Newslink, December 13, 2001 ("Enron's Bust: Was It the Result of OverConfidence or a Confidence Game?"); Accenture Outlook Journal, January, 2000 ("Mergers \& Acquisitions: Irreconcilable Differences"). 
effect of overconfidence on merger frequency, then, is ambiguous. Overconfident managers are unambiguously more likely to conduct mergers only if they have sufficient internal resources. Moreover, if overconfidence increases merger frequency, it also lowers average deal quality and induces a lower average market reaction to the announcement of merger bids.

We test these hypotheses using a sample of 394 large U.S. firms from 1980 to 1994. We use CEOs' personal investment decisions to elicit their beliefs about their companies' future performance. Previous literature shows that risk averse CEOs should reduce their exposure to company-specific risk by exercising in-the-money executive stock options prior to expiration. ${ }^{4}$ A subset of CEOs in our data persistently fails to do so. They delay option exercise all the way until expiration, even when the underlying stock price exceeds rational exercise thresholds such as those derived in Hall and Murphy (2002). Moreover, they typically make losses from holding their options relative to a diversification strategy.

We link the beliefs CEOs reveal in their personal portfolio choices to their merger decisions. We find that CEOs who fail to diversify their personal portfolios are significantly more likely to conduct mergers at any point in time. The results hold when we identify such CEOs with a fixed-effect ("Longholder") or allow for variation over time ("Post-Longholder" and "Holder 67"). They are robust to controlling for standard merger determinants like Q, size, and cash flow, and using firm fixed effects to remove the impact of time-invariant firm characteristics. The effect is largest among firms with abundant internal resources and for diversifying acquisitions. Taking diversification as a proxy for value destruction, ${ }^{5}$ these results confirm the overconfidence hypothesis.

We also analyze the market's reaction to merger announcements, which provides a more direct measure of value creation. We find that investors react significantly more negatively to merger bids of Longholder CEOs. Over the three days around announcements, they lose on average 90 basis points, compared to 12 basis points for other CEOs.

$\overline{4}$ See, e.g., Lambert et al. (1991).

5 Graham, Lemmon, and Wolf (2002) and Villalonga (2004), among others, question the interpretation of the diversification discount and attribute the effect to pre-existing discounts or econometric and data biases. Schoar (2002), however, confirms the negative impact of diversification via acquisition using plant-level data. 
The result holds controlling for relatedness of target and acquiror, ownership stake of the acquiring CEO, board size of the acquiror, and method of financing. While announcement effects may not capture the overall value created by mergers, due to market frictions and inefficiencies (Shleifer and Vishny, 2003; Mitchell, Pulvino, and Stafford, 2004), the differential reaction to bids of Longholder CEOs is likely to be orthogonal to these factors and, thus, to capture value differences.

We consider several explanations for the link between late option exercise and mergers: positive inside information, signaling, board pressure, risk tolerance, taxes, procrastination, and overconfidence. Only positive CEO beliefs (inside information or overconfidence) and risk preferences (risk tolerance), however, provide a straightforward explanation for both personal overinvestment and excessive merger activity. Among these explanations inside information (or signaling) is hard to reconcile with the losses CEOs incur on their personal portfolios by delaying option exercise and with the more negative reaction to their merger bids. Similarly, risk seeking is difficult to reconcile with the observed preference for cash financing and diversifying mergers. Overconfidence, instead, is consistent with all findings.

To further test the overconfidence interpretation, we hand-collect data on CEO coverage in the business press. We identify CEOs characterized as "confident" or "optimistic" versus "reliable," "cautious," "conservative," "practical," "frugal," or "steady." Characterization as confident or optimistic is significantly positively correlated with our portfolio measures of optimistic beliefs. And, our main results replicate using a press-based measure of overconfidence.

Our results suggest that a significant subset of CEOs is overconfident about their future cash flows and engages in mergers that do not warrant the paid premium. Overconfidence may create firm value along some dimensions-for example, by counteracting risk aversion, inducing entrepreneurship, allowing firms to make credible threats, or attracting similarly-minded employees ${ }^{6}$-but mergers are not among them.

Our paper relates to several strands of literature. First, we contribute to research on

$\overline{6}$ See Bernardo and Welch (2001), Goel and Thakor (2000), Schelling (1960), and Van den Steen (2005). 
the explanations for mergers. Much of the literature focuses on the efficiency gains from mergers (e.g., Lang, Stulz, and Walkling, 1989; Servaes, 1991; Mulherin and Poulsen, 1998). Overconfidence, instead, is closest to agency theory (Jensen, 1986 and 1988). Empire-building, like overconfidence, predicts heightened acquisitiveness to the detriment of shareholders, especially given abundant internal resources (Harford, 1999). Unlike traditional empire-builders, however, overconfident CEOs believe that they are acting in the interest of shareholders, and are willing to personally invest in their companies. Thus, while excessive acquisitiveness can result both from agency problems and from overconfidence, the relation to late option exercise, i.e., CEOs' personal overinvestment in their companies, arises only from overconfidence.

The paper also contributes to the literature on overconfidence. Psychologists suggest that individuals are especially overconfident about outcomes they believe are under their control (Langer, 1975; March and Shapira, 1987) and to which they are highly committed (Weinstein, 1980; Weinstein and Klein, 2002). ${ }^{7}$ Both criteria apply to mergers. The CEO gains control of the target. And a successful merger enhances professional standing and personal wealth.

We also contribute to the growing strand of behavioral corporate finance literature considering the consequences of biased managers in efficient markets (Barberis and Thaler, 2003; Baker, Ruback, and Wurgler, 2006; Camerer and Malmendier, 2007). A number of recent papers study upward biases in managers' self-assessment, focusing on corporate finance theory (Heaton, 2002), the decision-making of entrepreneurs (Landier and Thesmar, 2003), or indirect measures of "hubris" (Hayward and Hambrick, 1997). We complement the literature by using the decisions of CEOs in large companies to measure biased managerial beliefs and their implications for merger decisions. Seyhun (1990) also considers insider stock transactions around mergers, though overconfidence is not his primary focus. Our approach is most similar to Malmendier and Tate (2005),

$\overline{7}$ The overestimation of future outcomes, as analyzed in this literature, is sometimes referred to as "optimism" rather than "overconfidence," while "overconfidence" is used to denote the underestimation of confidence intervals. We follow the literature on self-serving attribution and choose the label "overconfidence" for the overestimation of outcomes related to own abilities (such as IQ or managerial skills) and "optimism" for the overestimation of exogenous outcomes (such as the growth of the U.S. economy). 
but improves the identification and test of overconfidence in two important ways: by directly measuring the value consequences of corporate decisions and by constructing an alternative media-based proxy.

The paper is organized as follows. Section 2 derives the empirical predictions of managerial overconfidence for mergers. Section 3 introduces the data. Section 4 develops our empirical measures of delayed option exercise. Section 5 describes the empirical strategy and relates late option exercise to heightened acquisitiveness and more negative market reactions to merger bids. Section 6 discusses alternative interpretations of the link between late exercise and mergers and derives a press-based measure of overconfidence. Section 7 concludes.

\section{Empirical predictions}

We analyze the impact of overconfidence on mergers in a general setting that allows for market inefficiencies, such as information asymmetries, and managerial frictions, such as agency costs and private benefits. ${ }^{8}$ We assume that these frictions and the quality of merger opportunities do not vary systematically between overconfident and rational CEOs, i.e., that overconfident and rational CEOs sort randomly across firms over time. When we test the resulting predictions, we account for violations of this assumption using a host of firm and manager level controls.

Overconfident managers overestimate their ability to create value. As a result, they overestimate the returns they can generate both in their own company and by taking over other firms. These two manifestations of overconfidence generate a trade-off when considering potential mergers. The overestimation of merger synergies induces excessive willingness to acquire other firms. But, the overestimation of stand-alone value generates perceived financing costs: potential lenders demand a higher interest rate and potential new shareholders demand lower issuance prices than the CEO deems appropriate given future returns. As a result, the CEO may forgo value-creating mergers he perceives to be

8 We derive these and further predictions formally in a more stylized setting in Malmendier and Tate (2004). 
too costly to finance, even if investors evaluate the company and the merger correctly. Thus, the net effect of overconfidence on merger frequency is ambiguous. A positive net effect would indicate that overconfidence is an important explanation of merger activity in practice, but is not a necessary implication of overconfidence.

Overconfidence unambiguously predicts more mergers, however, when the CEO does not need to access external capital markets to finance the deal. In firms with large cash stocks or spare riskless debt capacity, only the overestimation of synergies impacts the merger decisions of overconfident CEOs. We obtain the following prediction:

Prediction 1. In firms with abundant internal resources, overconfident CEOs are more likely to conduct acquisitions than non-overconfident CEOs.

Overconfidence also has implications for the value created by mergers. Since overconfident managers overestimate merger synergies, they misperceive some merger opportunities with negative synergies to be value-creating. As a result, they are more likely to undertake value-destroying projects that rational managers would forgo. Moreover, overconfident managers may have too high a reservation price for the target firm. Thus, if they compete with another bidder or if the target has significant bargaining power, they may overpay. ${ }^{9}$

Overconfident CEOs may also forgo some value-creating mergers due to perceived financing costs. Abstaining from a value-creating deal lowers shareholder value (though it improves average deal quality if the forgone deal is below average). Hence, we have the following prediction:

Prediction 2. If overconfident CEOs do more mergers than rational CEOs, then the average value created in mergers is lower for overconfident than for rational CEOs.

Note that overconfidence does not necessarily predict a negative reaction to merger bids. Rational managers may do some value-destroying deals or forgo some value-creating deals due to other frictions. In the latter case, some of the extra mergers of overconfident

$\overline{9}$ Note that, contrary to Roll's (1986) theory, an overconfident CEO does not always bid higher than a rational bidder. A CEO who is more overconfident about the value of his firm than about the merger may lose the contest due to perceived financing costs. 
CEOs may create value (as in Goel and Thakor, 2000). However, as long as overconfident CEOs undertake more mergers, the average announcement effect for bids by overconfident CEOs will be lower than the average announcement effect among rational CEOs.

\section{Data}

Our starting sample consists of 477 large publicly-traded U.S. firms from 1980 to 1994. The core of the data set is described in detail in Hall and Liebman (1998) and Yermack (1995). To be included in the sample, a firm must appear at least four times on one of the Forbes magazine lists of largest U.S. companies from 1984 to $1994 .{ }^{10}$ The virtue of this data set is its detailed information on CEOs stock and option holdings. We observe, in each sample year, the number of remaining options from the grants the CEO received in each of his prior years in office as well as the remaining duration and strike price. The data provide a fairly detailed picture of the CEO's portfolio rebalancing over his tenure.

We also collect data on articles about the CEOs in The New York Times, BusinessWeek, Financial Times, and The Economist using LexisNexis and in the The Wall Street Journal using Factiva.com. For each CEO and sample year, we record (1) the total number of articles, (2) the number of articles containing the words "confident" or "confidence," (3) the number of articles using "optimistic" or "optimism," (4) the number of articles using "reliable," "cautious," "conservative," "practical," "frugal," or "steady." We hand-check that the terms describe the CEO and separate out articles in which "confident" or "optimistic" are negated. ${ }^{11}$

We use the Securities Data Company (SDC) and Center for Research in Security Prices (CRSP) merger databases to obtain announcement dates and merger financing information for completed deals by our sample firms. The CRSP data set covers only

\footnotetext{
$\overline{10}$ This criterion excludes IPOs from our sample. Thus, the more stringent restrictions on trading associated with such firms, such as lockup periods, do not apply.

${ }^{11}$ Our search procedure also ensures that the words "overconfidence," "overconfident," "overoptimistic," and "overoptimism" (with or without hyphenation) will show up in categories (2) and $(3)$.
} 
mergers with CRSP-listed targets. We use SDC to supplement the data with acquisitions of private firms, large subsidiaries, and foreign companies. ${ }^{12}$ We require that the acquiring company obtains at least $51 \%$ of the target shares (and, hence, control) and omit acquisitions in which the acquiror already holds at least $51 \%$ of the target before the deal. Finally, following Morck et al. (1990), we omit acquisitions worth less than 5\% of acquiror value. ${ }^{13}$

We supplement the data with various items from the Compustat database. We measure firm size as the natural logarithm of assets (item 6) at the beginning of the year, investment as capital expenditures (item 128), cash flow as earnings before extraordinary items (item 18) plus depreciation (item 14), and capital as property, plants and equipment (item 8). We normalize cash flow by beginning-of-the-year capital. Given that our sample is not limited to manufacturing firms (though it mainly consists of large, non-financial firms), we check the robustness of our results to normalization by assets (item 6). We measure $\mathrm{Q}$ as the ratio of market value of assets to book value of assets. Market value of assets is defined as total assets (item 6) plus market equity minus book equity. Market equity is defined as common shares outstanding (item 25) times fiscal year closing price (item 199). Book equity is calculated as stockholders' equity (item 216) [or the first available of common equity (item 60) plus preferred stock par value (item 130) or total assets (item 6) minus total liabilities (item 181)] minus preferred stock liquidating value (item 10) [or the first available of redemption value (item 56) or par value (item 130)] plus balance sheet deferred taxes and investment tax credit (item 35) when available minus post retirement assets (item 330) when available. Book value of assets is total assets (item 6). ${ }^{14}$ We use fiscal year closing prices (item 199) adjusted for stock splits (item 27) to calculate annual stock returns. Our calculation of annual returns excludes dividends; we consider the impact of capital appreciation and dividend payments separately in Section 6. We use CRSP to gather stock prices and Standard

\footnotetext{
${ }^{12}$ All results are robust to using only CRSP data, i.e., mergers involving publicly traded U.S. targets.

13 This criterion is important when using SDC data since acquisitions of small units of another company differ substantially from those of large NYSE firms and may not require active involvement of the acquiror's CEO.

${ }^{14}$ Definitions of Q and its components as in Fama and French (2002).
} 
Industrial Classification (SIC) codes. Missing accounting data (largely of financial firms) leaves us with a final sample of 394 firms. As in Malmendier and Tate (2005), we trim cash flow at the $1 \%$ level to ensure that our results are not driven by outliers. However, all results replicate with the full data.

In addition, we collect personal information about the CEOs using Dun and Bradstreet (1997) and Who's Who in Finance and Industry (1980/81-1995/96). We broadly classify a CEO's educational background as financial, technical, or miscellaneous. CEOs have finance education if they hold undergraduate or graduate degrees in accounting, finance, business (including an MBA), or economics. They have technical education if they hold undergraduate or graduate degrees in engineering, physics, operations research, chemistry, mathematics, biology, pharmacy, or other applied sciences.

Table 1 presents summary statistics of the data. Panel A presents firm-specific variables. Our sample firms are large, and most (48\%) are in the manufacturing industry. Panel B shows CEO-specific variables, both for the full set of CEOs and for the subset of CEOs whom we classify as overconfident based on their option-exercise behavior ("Longholder," see Section 4). The means, medians and standard deviations of all variables are remarkably similar for Longholder and non-Longholder CEOs. Only the number of vested options that have not been exercised is considerably higher among Longholder CEOs. This difference could stem from overconfidence, as we will see later. But, regardless, we will control for the level of vested options in all of our regressions. Panel $\mathrm{C}$ presents the summary statistics of the CEOs' press coverage. While the mean and median number of annual mentions are relatively high (8.89 and 3), mentions with the attributes "confident" or "optimistic" or any of "reliable," "cautious," "conservative," "practical," "steady," and "frugal" are infrequent (the means are below 0.1 and the medians are 0). Our analysis will use dummy variables, which indicate differences in the number of mentions of each type, in lieu of the raw numbers of articles in each category. Finally, Panel D presents summary statistics of the mergers undertaken by CEOs in our sample. Notably, the acquiror's stock has a negative cumulative abnormal return of 29 basis points on average over the three day window surrounding the announcement of a merger bid. 


\section{Measuring overconfidence}

We use the panel data on CEOs' personal portfolios to identify differences across managers in executive option exercise. Executive options give the holder the right to purchase company stock, usually at the stock price on the grant date. Most executive options have a ten-year life span and are fully exercisable after a four-year vesting period. Upon exercise, the holder receives shares of company stock. These shares are almost always immediately sold (Ofek and Yermack, 2000).

Merton (1973) shows that investors should not exercise options early since the right to delay purchasing the underlying stock has non-negative value and investors are free to diversify. This logic does not apply to executive options. Executive options are nontradeable, and CEOs cannot hedge (legally) the risk of their holdings by short-selling company stock. CEOs are also highly exposed to company risk since a large part of their compensation is equity-based and their human capital is invested in their firms. As a result, risk-averse CEOs should exercise options early if the stock price is sufficiently high (Lambert et al., 1991; Hall and Murphy, 2002), i.e., when the marginal cost of continuing to hold the option (risk exposure) exceeds the marginal benefit (option value). The exact threshold for exercise depends on remaining option duration, individual wealth, the degree of underdiversification, and risk aversion.

In our sample of FORBES 500 CEOs, the high degree of underdiversification implies fairly low thresholds, given reasonable calibrations of wealth and risk aversion. A subset of CEOs, however, persistently fails to exercise highly in-the-money vested options. One interpretation of this failure to exercise is overconfidence, i.e., overestimation of the firm's future returns. Other interpretations include positive inside information, signaling, board pressure, risk tolerance, taxes, and procrastination. After relating late option exercise to merger decisions (Section 5), we will discuss these alternative interpretations (Section 6.1.).

We construct three indicator variables, which partition our CEOs into "late" and "timely" option exercisers.

Longholder. Our first indicator variable identifies CEOs who, at least once during 
their tenure, hold an option until the year of expiration, even though the option is at least $40 \%$ in the money entering its final year. The exercise threshold of $40 \%$ is calibrated using the model of Hall and Murphy (2002) with a constant relative risk aversion (CRRA) of three and $67 \%$ of wealth in company stock, and refines the Longholder measure in Malmendier and Tate (2005). The particular choice of parameter values is not important for our results: the median percentage in-the-money entering the final year for options held to expiration is 253. Any assumption from no threshold at all to a threshold of $100 \%$ yields similar results. ${ }^{15}$ We apply this measure as a managerial fixed effect, denoted Longholder.

We construct two alternative indicators of late exercise which (1) allow for time variation over a manager's sample years and (2) eliminate forward-looking information from the classification.

Pre-/Post-Longholder. First, we split the Longholder indicator into two separate dummy variables. Post-Longholder is equal to 1 only after the CEO for the first time holds an option until expiration (provided it exceeds the $40 \%$ threshold). Pre-Longholder is equal to 1 for the rest of the CEO years in which Longholder is equal to 1 .

One shortcoming of Post-Longholder is its lack of power. Only $42 \%$ of the observations in which Longholder is 1 fall into the Post-Longholder category, capturing 74 mergers. This effectively excludes the Post-Longholder measure from tests that require us to subdivide mergers into finer categories (cash versus stock or diversifying versus intraindustry mergers).

Holder 67. We construct a second backward-looking measure, Holder 67, which relaxes the requirement that CEOs hold their options all the way until expiration. ${ }^{16}$ Instead, we focus on the exercise decision in the fifth year prior to expiration. Five years before expiration is the earliest point we can consider since most options in our

\footnotetext{
${ }^{15}$ See Fig. 1 in the NBER working paper version, Malmendier and Tate (2004). We do not calculate a separate threshold for every option package, depending on the CEO's wealth, diversification, and risk aversion, as we cannot observe these characteristics. Individual calibration would introduce observation-specific noise into the estimation without clear benefits.

16 The definition of Holder 67 differs from the definition in Malmendier and Tate (2005), most importantly in removing all forward-looking information.
} 
sample have a ten-year duration and are fully vested only after year four. We drop the small number of option packages with five years remaining duration that are not fully vested. ${ }^{17}$ Maintaining the previous assumptions on constant relative risk aversion and diversification, the new exercise threshold in the Hall-Murphy framework is $67 \%$. We set Holder 67 equal to 1 if a $\mathrm{CEO}$ fails to exercise options with five years remaining duration despite a $67 \%$ increase in stock price (or more) since the grant date. As above, the results are robust to variation in the value of the threshold.

When we use this proxy, we consider only CEOs who could have been classified as Holder 67. That is, a CEO enters the sample once he has an option with five years remaining duration that is at least $67 \%$ in the money. Once he postpones the exercise of such options he is classified as Holder 67 and retains that label for his remaining sample years. The selection criterion controls for the impact of past performance: all CEOs experienced (at least) a $67 \%$ appreciation in stock prices between the grant and vesting dates of their options. Overall, the sample restrictions leave 1,667 of our original 3,911 observations. Because of the less stringent requirements of Holder 67, there are more late-exercise CEO-years and completed mergers (232) than under Post-Longholder, making the measure more appropriate for split-sample estimations.

In Table 2, we report the pairwise correlations between the Longholder measure and firm and CEO characteristics. (The patterns are similar for the other portfolio measures.) The correlations are generally low. The only two variables with correlations higher than 0.1 with Longholder are CEO vested options and tenure. These correlations may arise mechanistically since classification as Longholder requires the CEO to hold options for ten years (typically) to expiration. The correlation with tenure does not arise for Holder 67 . The (untabulated) correlation between Holder 67 and tenure is -0.012 . However, the correlation with vested options is also large for Holder 67 (0.21). Vested option holdings, then, might also proxy for excessive exposure to company risk. However, exposure due to vested option holdings reflects both the CEO's choice and board choices on compensation and contract provisions. Longholder and Holder 67 instead only reflect the CEO's choice not to diversify. We will control for option holdings and tenure in our estimations to

$\overline{17}$ These rare cases are options with fewer than ten years duration. 
prevent their direct effects from contaminating our results.

Finally, we find that the different measures of failure to exercise are significantly correlated with each other: the correlation between Longholder and Holder 67 is 0.47 .

\section{Overconfidence and acquisitiveness}

Our empirical analysis relates CEOs' personal portfolio decisions to their corporate decisions. We test whether CEOs in cash-rich firms who maintain high personal exposure to company risk are more acquisitive and whether their mergers create less value on average.

We begin by measuring the unconditional relation between late option exercise and merger frequency. In Fig. 1, we plot merger frequency among Longholder CEOs and their peers over time. The fraction of Longholder CEOs making at least one acquisition is higher in most years (up to 414\%), often significantly so. Overall, Longholder CEOs do at least one merger in 108 out of 662 firm-years. For almost five times as many $(3,249)$ firm-years, their peers do mergers in only three times as many (343) years. Aggregating over time, the odds of a Longholder CEO making at least one acquisition are 1.65 times the odds of other CEOs (significant at 1\%). ${ }^{18}$ The pattern in the number of mergers per CEO is even stronger (Fig. 2). Longholders surpass their peers in all but two years. The pictures are also similar using merger bids instead of completed mergers or using our other measures of late exercise: the odds ratio for making at least one acquisition is 1.48 for Post-Longholder (significant at 10\%) and 1.62 for Holder 67 (significant at 1\%). This strong unconditional relation between late exercise and merger frequency suggests that overconfidence may be a significant determinant of mergers.

\subsection{Merger frequency and internal resources}

We formalize this evidence and test Prediction 1 using the following regression specification:

$$
\operatorname{Pr}\left\{Y_{i t}=1 \mid O_{i t}, X_{i t}\right\}=G\left(\beta_{1}+\beta_{2} O_{i t}+X_{i t}^{\prime} B\right) .
$$

$\overline{18}$ The odds are 0.195 for Longholder CEOs and 0.118 for the rest. 
$O$ is the overconfidence measure and $X$ a set of controls. $Y$ is a binary variable that takes the value 1 if the CEO made at least one successful merger bid in a particular firm year. Throughout the paper, we assume that $G$ is the logistic distribution. ${ }^{19}$ The null hypothesis is that $\beta_{2}$, the coefficient on the overconfidence proxy, is equal to zero. We report the results of two-tailed tests even though the overconfidence theory motivates one-sided hypothesis tests. Thus, significance at the $10 \%$ level can be interpreted as significance at the $5 \%$ level for the theoretically derived one-sided test.

As described in Section 4, we use several proxies for $O$. Our first measure, Longholder, uses two types of variation: cross-sectional and within-firm variation. As an example for cross-sectional identification, consider the case of Wayne Huizenga, CEO of Blockbuster Entertainment Group for all seven years the firm appears in our data. Since he holds some options until the year of expiration, we classify him as overconfident. He also conducts seven acquisitions during those seven years. Similarly, David Farrell is the CEO of May Department Stores-the holding company of Lord \& Taylor, Filene's, and RobinsonsMay, among others-for the 15 years the firm appears in our sample and is classified as overconfident. He conducts five mergers during those 15 years. By contrast, J. Willard Marriott is the CEO of Marriott International for all 15 years of our sample, but never holds an option until expiration. He also never conducts an acquisition. By comparing these two types of CEOs, we can identify a cross-sectional effect of overconfidence on acquisitiveness.

As an example of within-firm variation, consider Colgate Palmolive. For the first four years, the CEO is Keith Crane. Crane never holds an option until expiration and he never conducts an acquisition. Reuben Mark succeeds him as CEO in 1984. Over the next 11 years, he holds some options until the year of expiration and he also conducts four acquisitions. By comparing overconfident and rational CEOs within the same firm, we might also identify a positive effect of overconfidence on acquisitiveness.

The Holder 67 measure, on the other hand, can vary within CEO. It exploits changes in CEOs' option exercise behavior in addition to the two sources of variation described

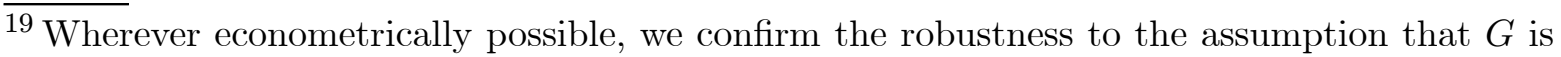
normal.
} 
above. Longholder Wayne Huizenga, for example, does not exercise two option packages that have passed the $67 \%$ threshold with five years remaining duration. From 1987 to 1989, before he is classified as Holder 67, he does four acquisitions. From 1990 through 1994, he does another three. Similarly, David Farrell, a Longholder, fails to exercise an option that has reached the $67 \%$ threshold in 1986. From 1980 to 1986, he completes two acquisitions. From 1987 through 1995, after he becomes a Holder 67, he does three more.

We estimate Eq. (1) using three procedures. First, we estimate pooled logit regressions, which use all types of variation. Second, we estimate logit regressions with random effects, which also use all sources of variation, but explicitly model the effect of the firm on acquisitiveness. If the estimated effects of overconfidence in the pooled specification were due to firm effects, the estimates should decline when we include random effects. Third, we estimate logit regressions with firm fixed effects. This specification makes use only of within-firm and within-CEO variation. That is, we estimate the effect of overconfidence on acquisitiveness using only variation between overconfident and rational CEOs within firms and (in the case of Holder 67) between CEOs' overconfident and rational years. To address the incidental parameters problem, we estimate the fixed-effects model with a conditional logit regression. Conditioning the likelihood on the number of successes in each panel, we avoid estimating the coefficients of the fixed effects and obtain consistent estimates of the remaining coefficients. The advantage of the fixed-effects approach is that it eliminates any time-invariant firm effect on acquisitiveness. The disadvantage is that it induces sample selection. Only firms that conduct at least one merger during the sample period are included in the conditional logit estimation, and only firms that had at least one overconfident and one non-overconfident CEO during the sample period (or a CEO who switches from not overconfident to overconfident under Holder 67) are used to identify $\beta_{2}$. We cluster standard errors in the pooled and fixed-effects logits to account for heteroskedasticity and auto-correlation at the firm level. ${ }^{20}$ We tabulate only the

\footnotetext{
${ }^{20}$ We verify the robustness of the results to clustering at the CEO rather than the firm level. Firm-level clustering is more stringent since it allows for the possibility that all of the firm's errors are correlated. CEO-level clustering instead assumes that observations of different CEOs within the same firm are independent.
} 
most stringent, fixed-effects specification, except in the split-sample analyses where the number of identifiable cases is too small. In these cases, we tabulate the random-effects specification. In all other cases, the results are robust across estimation procedures.

Table 3 presents two sets of results. In the left half of the table, we test the robustness of the unconditional patterns in Figs. 1 and 2 to the inclusion of firm- and CEO-level controls. We include the following firm-level controls ${ }^{21}$ : the logarithm of assets at the beginning of the year as a control for firm size, Tobin's Q at the beginning of the year as a control for investment opportunities, cash flow as a measure of internal resources, an indicator for efficient board size (at most 12 members) ${ }^{22}$ as a measure of corporate governance, and firm fixed effects. At the CEO-level, we include two controls for the incentive effects of stock and options: the percent of company stock held by the CEO at the beginning of the year and the number of options exercisable within six months of the beginning of the year, normalized by total shares outstanding. ${ }^{23}$ We include year effects to control for time trends in the likelihood of conducting a merger. The coefficient estimates are presented as odds ratios. Thus, to test for a positive effect on acquisitiveness, we compare the reported estimates to 1.

Among the controls, we consistently find that firms with lower Tobin's Q are more acquisitive, suggesting that acquisitions may substitute for profitable investment opportunities. ${ }^{24}$ More cash flow generally leads to more merger activity, as expected if cash eases financing constraints. Vested option holdings predict fewer mergers. The withinfirm effect of size on acquisitiveness is positive; however, the relationship may be mecha-

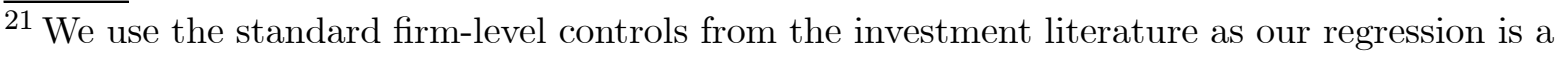
binary investment model.

22 The results are robust to using the logarithm of board size or the number (or percentage) of CEOs of other firms sitting on the board. The firm fixed effects capture most of the remaining variation in governance since firm governance is very stable over our sample period. (See Guner et al., forthcoming, for a detailed analysis of board composition in a closely related data set.) Recent measures such as the Gompers, Ishii, Metrick (2003) index are not available for our 1980-1994 sample period.

${ }^{23}$ We multiply vested option holdings by ten so that the mean is similar to stock ownership.

24 This effect appears to be non-monotonic. For example, we find a positive and marginally significant effect when we include a dummy variable for "high Tobin's Q" $(Q>1)$. Alternatively, including the square of Tobin's Q reverses the direction of the level effect (though it becomes insignificant). 
nistic since the assets of a firm must increase during a merger. We re-run the regressions without size and verify that this effect does not change the estimates of $\beta_{2}$. Finally, the effects of efficient board size and stock ownership are typically insignificant.

Turning to the coefficient of interest, the effect of late exercise on merger frequency remains positive after including all the controls and fixed effects. CEOs who persistently hold options are significantly more acquisitive, even when we identify $\beta_{2}$ using only variation across CEOs or (for Holder 67) within CEOs in the same firm.

In the right half of Table 3, we test Prediction 1: are overconfident CEOs more acquisitive in firms with abundant internal resources? Since overconfident CEOs both overestimate the returns to mergers and perceive their stand-alone firms to be undervalued, they view issuing equity or taking risky debt to be costly, even when investors evaluate their firms correctly. The perceived costs do not affect the decision to merge only if the merger can be financed internally. We test whether CEOs who fail to exercise in-the-money options are more acquisitive than their peers when in cash-rich firms.

Note that traditional agency theory generates a different prediction. Empire-building CEOs also waste free cash flow on bad acquisitions (Harford, 1999). But, unlike overconfident CEOs, they are aware that their mergers destroy shareholder value. As a result, they should minimize their personal investment in the company by exercising in-the-money options at the earliest opportunity. Personal investment in the company, as measured by our controls for stock and option holdings, should decrease an empire-building CEO's propensity to acquire since it aligns CEO and shareholder interests. Our measures of late exercise, instead, isolate the active decision of the CEO not to divest company risk. This behavior and the link to increased acquisitiveness distinguishes overconfidence from traditional agency theory.

We identify cash-rich and cash-poor firms using the model of Harford (1999). In a first stage, we regress cash reserves (cash stock normalized by sales) on the change in the risk premium between AAA and Baa bonds, a dummy for NBER recession years, the ratio of market to book value of assets, the coefficient of variation of operating cash flows, firm size (market value), and the level of and changes from year $t$ to $t+1$ and $t+1$ to $t+2$ in operating cash flow net of investment (normalized by sales). In our sample, the model 
explains $84 \%$ of the variation in cash reserves. Following Harford, we call firm-years "cash rich" if beginning-of-the-year cash reserves are at least 1.5 standard deviations above the value predicted by the baseline model, where the standard deviation is the time series deviation in firm cash reserves.

We estimate random-effects logit regressions of Eq. (1) on all firm years for which the Harford model is defined (Column 4), on "cash rich" firm-years (Column 5), and on the remaining firm-years (Column 6). ${ }^{25}$

Among the controls, the estimated effect of Tobin's Q is similar to the full-sample estimation: firms with lower Tobin's Q are more acquisitive. The effect of cash flow on acquisitiveness depends on whether the firm is cash-rich or cash-poor. Cash flow increases acquisitiveness among cash-poor firms. But, among cash-rich firms there is no significant effect of cash flow on acquisitiveness suggesting that cash constraints do not bind. This result corroborates the classification of the Harford model. The effects of stock ownership and vested options are insignificant in all specifications except Column 5 (cash-rich subsample), in which the Stock Ownership odds ratio appears to "blow up." The Longholder effect is robust to excluding this control variable. Finally, efficient board size predicts less acquisitiveness in cash-rich firms, but not in cash-poor firms, consistent with traditional agency theory.

Turning to the coefficient of interest, we find that Longholder CEOs are significantly more likely to make acquisitions than other CEOs not only in the full sample, but also in the subsample of cash-rich firm-years as predicted by the overconfidence model (odds ratio $=1.97$, significant at $5 \%$ ). We also find a significant effect in the cash-poor subsample (odds ratio $=1.55$, significant at 5\%). A Wald test fails to reject equality of the estimates in the two subsamples. The latter finding neither confirms nor rejects the overconfidence hypothesis: the CEO's decision in constrained firms depends on the unobservable relation between overestimated gains to merging and perceived own-company undervaluation. Hence, overconfidence may or may not have a significant impact on acquisitiveness in cash-poor firms. The results are similar using Holder 67 (cash-rich odds

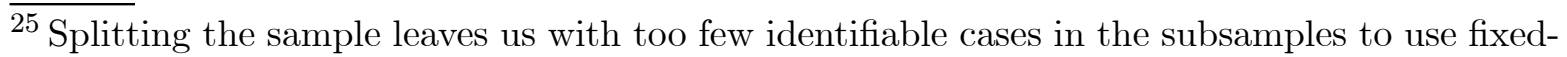
effects logit. 
ratio $=2.14$, significant at $5 \%$; cash-poor odds ratio $=1.39$, insignificant)

We find similar results if we measure internal resources using the Kaplan-Zingales index rather than the Harford model. The index, based on logit estimates from Kaplan and Zingales (1997), is defined as

$$
\begin{aligned}
K Z_{i t}= & -1.001909 * \frac{C F_{i t}}{K_{i t-1}}+0.2826389 * Q_{i t}+3.139193 * L e v_{i t}-39.3678 * \frac{D i v_{i t}}{K_{i t-1}} \\
& -1.314759 * \frac{C_{i t}}{K_{i t-1}}
\end{aligned}
$$

where $C F / K$ is cash flow to capital, Lev is debt to total capital, Div/K is dividends to capital, and $C / K$ is cash holdings to capital. ${ }^{26}$ Higher values imply higher constraints. Following recent research (Baker et al., 2003; Lamont et al., 2001; Malmendier and Tate, 2005), we use the twice-lagged value of the index to split sample firms into quintiles and estimate random-effects logit regressions of Eq. (1) separately on each quintile. The Longholder coefficient is positive and significant in the "least constrained" quintile (odds ratio $=2.03$, significant at $5 \%$ ) and insignificant in the "most constrained" quintile (odds ratio $=1.07)$. Again, the cross-quintile difference is not significant at conventional levels $(\mathrm{p}$-value $=0.133) .{ }^{27}$

Finally, we test the effect of perceived undervaluation directly by looking at merger financing. We find that, conditional on conducting a merger, Longholder CEOs are more likely to finance it using cash (Panel A, Table 4). The odds ratio of using cash versus any mixture of risky securities with cash is 1.10. It is even stronger for the Holder 67 measure (1.38; untabulated). We also examine the effect in a regression framework, controlling for above- or below-average firm valuation (relative to its industry), Tobin's Q, CEO stock and vested option ownership, merger size, the availability of internal funds, and year effects in various combinations (Panel B). The odds ratio increases to

${ }^{26}$ For this test, we use the definition of Q employed by Kaplan and Zingales (1997) to avoid rendering the weights meaningless. The Compustat data items are: cash flow to capital = (item $18+$ item 14) / item $8 ; \mathrm{Q}=[\operatorname{item} 6+($ item $24 *$ item 25$)$ - item 60 - item 74$] /$ item 6 ; debt to total capital (leverage) $=($ item $9+$ item 34$) /($ item $9+$ item $34+$ item 216$)$; dividends to capital $=$ item $21+$ item 19$) /$ item $8 ; \operatorname{cash}$ to capital $=$ item $1 /$ item 8 . Item 8, capital, is always taken at the beginning of the year (lagged).

27 There are too few observations in quintiles of the Holder 67 sample to allow a similar analysis. 
1.2 but is insignificant. It is 1.7 and significant at the $10 \%$ level for Holder 67 . It is also significant for Longholder CEOs when the firm is unlikely to be (objectively) overvalued, i.e., when Tobin's $\mathrm{Q}$ is less than the (within-sample) industry average. The interaction of "undervaluation" and Longholder is significant in all specifications.

The financing results allow us to disentangle the two manifestations of overconfidence in the context of mergers: managers who are overconfident about the returns they generate overestimate both the value they create in their own firm and the value they create by taking over other firms. The overconfidence hypothesis predicts that the two types of overestimation are linked and that their relative importance varies with the market valuation of the own company. In times of high market valuation, captured by high $\mathrm{Q}$ relative to the industry, the $\mathrm{CEO}$ is less likely to perceive his own company to be undervalued. In this case, even overconfident managers are willing to finance deals using equity. The results are also consistent with the view that investor sentiment affects merger financing decisions, as in Shleifer and Vishny (2003).

\subsection{Value consequences}

Next we test Prediction 2. We ask whether the heightened acquisitiveness of lateexercising CEOs leads to an increased propensity to take projects with negative expected returns. We first use deal characteristics as a rough measure of quality. We then measure differences in the market's reaction to bids by Longholder and other CEOs.

\subsubsection{Diversification}

First, we use diversification as a proxy for deal quality. Many prior studies find evidence of a diversification discount. ${ }^{28}$ Plant-level data confirm the negative impact of diversification via acquisition and address concerns about econometric and data biases. ${ }^{29}$ Moreover, the market seems to anticipate that many diversifying bids are unwise. Morck et al. (1990) measure negative announcement effects to diversifying deals, an effect we

$\overline{28}$ See, e.g., Lang and Stulz (1994), Berger and Ofek (1995), Servaes (1996), and Lamont and Polk (2002).

${ }^{29}$ Schoar (2002), addressing Graham, Lemmon, and Wolf (2002) and Villalonga (2004) among others. 
confirm in our data. ${ }^{30}$

We re-estimate Eq. (1) with a dependent variable that indicates diversifying merger bids and, separately, with a dependent variable that indicates intra-industry bids. ${ }^{31}$ We classify deals as diversifying if acquiror and target are not members of the same Fama-French 48 industry group. ${ }^{32}$ The results are in Column 1 of Table 5 . We find that Longholder CEOs are significantly more likely than other CEOs to do diversifying mergers (odds ratio $=2.54$, significant at $1 \%$ ), but not within-industry deals (odds ratio $=1.66)$. This result suggests that the extra mergers of late-exercisers may be disproportionately low quality. However, the cross-regression difference in coefficients is not significant. The (untabulated) results are similar using the Holder 67 measure (odds ratio $=2.72$, significant at $5 \%$; odds ratio $=0.84$, insignificant $)$.

We also measure differences in the propensity to diversify among cash-rich firms. As in Section 5.1., we measure internal resources using the model of Harford (1999) and estimate a random-effects model. In the full sample, the logit results replicate: Longholder CEOs are particularly likely to do diversifying deals (odds ratio $=2.01$, significant at 1\%), but are no more likely to do within-industry deals (odds ratio $=1.30$, insignificant). We find similar results for Longholder CEOs in cash-rich firms: the odds ratio is 2.50, significant at 5\%, for diversifying mergers, but insignificant for withinindustry mergers. In the cash-poor subsample, the pattern is similar, though weaker for diversifying deals (odds ratio $=1.78$, significant at $5 \%$ ). The same is true for Holder 67 (cash-rich diversifying odds ratio $=2.15$, significant at $10 \%$; cash-poor diversifying odds ratio $=1.86$, significant at 5\%; no significant effects within industries).

In unreported estimations, we check the robustness of these patterns to the inclusion of further controls for the agency effects of free cash flow. In addition to our controls

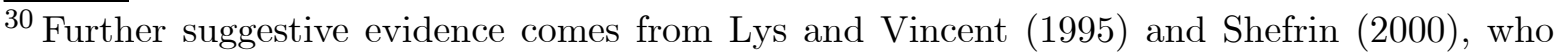
chronicle AT\&T's 1990 acquisition of NCR using exactly this paradigm. Interestingly, both the Longholder and Holder 67 measures identify AT\&T's CEO (Robert Allen) as overconfident. ${ }^{31}$ As before, we analyze merger bids that were ultimately successful. However, since the likelihood of failure may differ across diversifying and intra-industry mergers, we also perform the estimations including unsuccessful merger bids. None of our conclusions in this Section (as elsewhere in the paper) are affected.

${ }^{32}$ See Ken French's website http://mba.tuck.dartmouth.edu/pages/faculty/ken.french/data_library.html.
} 
for incentive misalignment (stock and option ownership), we include a measure of CEO power (consolidation of the titles CEO, Chairman of the Board, and President) and a continuous measure of the availability of cash reserves. The controls are typically insignificant and the effect of late exercise is largely unchanged.

In summary, we find that the point estimates for the effect of late exercise on excess acquisitiveness are always largest in the sample of cash-rich firms and for diversifying deals. The results suggest a mechanism by which overconfidence destroys shareholder value. However, we must be cautious in interpreting the results since the cross-sample differences are typically not significant. In the next subsection, we use different methodology to provide additional evidence.

\subsubsection{Market reaction}

Next we use announcement effects to test Prediction 2 more directly. When overconfident CEOs engage in more deals than other CEOs, their deals have lower average quality. Moreover, they may overbid, even in (otherwise) value-creating deals. As a result, the market reaction to merger bids should be significantly lower for overconfident than for non-overconfident CEOs.

We calculate the cumulative abnormal return to the acquiring firm's stock over a three-day window around the announcement of the merger bid, ${ }^{33}$ using the daily return on the S\&P 500 index as our proxy for expected returns. This approach is appropriate since our sample consists of large U.S. companies that comprise a substantial portion of market returns. ${ }^{34}$

The average announcement effect in our sample is -29 basis points (bp) in Panel A, Table 6. The market reaction to merger bids by Longholder CEOs is three times as negative as for the rest of the sample: among Longholder CEOs, the average effect is -90 bp (significant at 1\%) and among other CEOs it is $-12 \mathrm{bp}$ (insignificant). We can decompose these effects further based on the means of financing. Among non-Longholder CEOs, the reaction to cash bids is significantly positive (70 bp) and the reaction to

\footnotetext{
$\overline{33}$ We find similar results using a window of five days $(-2$ to +2$)$.

34 The standard market-model results (using a pre-estimation period to identify $\alpha$ and $\beta$ ) are almost identical.
} 
stock bids is significantly negative $(-75 \mathrm{bp}) .{ }^{35}$ Bids of Longholder CEOs, instead, always trigger a negative average reaction, though it is four times as large and significant only for stock bids $(-135 \mathrm{bp})$. Moreover, the negative reaction for Longholder CEOs is most pronounced in the subsample of firm-years classified as Post-Longholder. Here, the average effect is $-160 \mathrm{bp}$ (and $-277 \mathrm{bp}$ for stock bids). ${ }^{36}$

We test whether the negative contribution of overconfidence to cumulative abnormal returns holds controlling for firm and CEO characteristics using the following model:

$$
C A R_{i}=\gamma_{1}+\gamma_{2} O_{i}+X_{i}^{\prime} G+\varepsilon_{i}
$$

$O$ is the overconfidence proxy. The set of controls $X$ includes standard predictors of the market's reaction to merger bids: relatedness (an indicator for within-industry mergers) and cash financing. We continue to include controls for stock and option ownership and corporate governance (efficient board size). Lastly, we include year effects to control for time trends in the market reaction to merger bids and potential clustering of overconfident and non-overconfident bids in different merger waves. Since the dependent variable is continuous rather than binary, we switch from a logit specification to a linear regression. The null hypothesis is $\gamma_{2}=0$.

Panel B of Table 6 presents the results. The coefficient estimates of all controls have the expected signs. The two consistently significant controls are Cash Financing and Vested Options. Cash deals are, on average, viewed more favorably by the market. The effect of vested option holdings on cumulative abnormal returns is non-linear. The effect is positive at lower values, possibly due to improved incentives, and negative at high values, possibly due to entrenchment or excessive CEO power. We include a quadratic term to capture the non-linearity.

Most importantly, the market reaction to merger bids of Longholders is negative, confirming Prediction 2. Compared to the simple averages, the difference between Longholder CEOs and the remaining sample increases from -78 bp (significant at $5 \%$ ) to

\footnotetext{
$\overline{35}$ We define stock bids as bids in which any portion is financed using equity.

${ }^{36}$ Under the Holder 67 measure, the results are sensitive to the window of evaluation (i.e., $(-1,+1)$ versus $(-2,+2))$ and also to the inclusion or exclusion of failed merger bids. Inclusion gives us more power and leads to results more in line with the Longholder estimates.
} 
$-112 \mathrm{bp}$, or $-115 \mathrm{bp}$ with year effects (both significant at $1 \%$ ). The results are stronger for Post-Longholder firm-years (Columns 4 and 5). One interpretation is that the market discounts the bids of Longholder CEOs only after they have revealed their overconfidence through their portfolio decisions. Moreover, the results are robust to including additional controls for agency concerns, as in Section 5.2.1.

We can use the announcement effects to quantify the loss in shareholder wealth through merger bids by late-exercising CEOs. The Longholder measure identifies 10.8\% of CEOs as overconfident. If we calculate the value creation or destruction to acquiringcompany shareholders as announcement effect times market capitalization before announcement, we find that this $10.8 \%$ of CEOs causes $44 \%$ of value destruction around merger bids. Per bid, Longholders destroy on average $\$ 7.7$ million more value than other CEOs. Over the sample period, Longholder CEOs are responsible for the loss of $\$ 2.15$ billion to acquiring shareholders (out of $\$ 4.39$ billion total).

\section{Discussion}

There are many reasons why CEOs may hold options even when rational models suggest exercise. We first assess several such reasons in light of their consistency with the evidence and their ability to link late exercise to merger decisions. We then offer an additional measure of overconfidence, which further tightens the interpretation of the observed CEO behavior.

\subsection{Alternative explanations}

1. Taxes and Dividends. CEOs may delay the exercise of in-the-money options to postpone the payment of taxes on their profits. Personal income tax deferral, however, makes no direct prediction for merger decisions. Similarly, CEOs may accelerate option exercise to capture the dividend payments on the underlying shares. If firms are less likely to pay dividends around mergers, time series variation in dividend payments might link late exercise to merger decisions. We verify that our results are robust to including dividend payments as an additional control. 
2. Board Pressure (and corporate governance). Board pressure can explain both delay in option exercise and merger decisions. Directors may pressure CEOs to hold in-themoney options to signal the high quality of the firm's merger deals to the market. If this signaling is effective, the market should prefer the merger deals of option-holders to exercisers. We find in Section 5.2.2, however, that the opposite is the case.

Two possibilities remain: boards have incorrect beliefs about the signaling value of holding options; or, option holding does have positive signaling value and the market would have reacted even worse had the CEOs exercised their options. We have no evidence that directly addresses these stories. However, the inclusion of firm fixed effects largely controls for differences in board influence since board composition is remarkably stable over time in our data. More generally, it removes the influence of any unspecified firm-level variation in corporate governance.

3. Past Performance (and market inefficiencies). If good past performance reflects good opportunities, then CEOs in firms with a recent run-up in stock prices may both hold options and engage in acquisitions. Alternatively, if good past performance leads to overvaluation in an inefficient market, then CEOs may trade overvalued equity for the (real) assets of target firms (Shleifer and Vishny, 2003; Dong et al., 2006). Moreover, they may delay option exercise to reap the benefits of the bubble. Or they may want to avoid "popping" the bubble, if option exercise conveys a negative signal to the market. To address this possibility, we check whether merger frequency covaries with past performance and whether controlling for this effect reduces the coefficient of late exercise. We add five lags of stock returns ( $t-1$ to $t-5)$ to the controls in Eq. (1). We find a positive relation between the $(t-1)$ lag of returns and acquisitiveness in most specifications. The coefficient of late exercise, however, is not materially affected.

We also verify the robustness of our results to including fixed effects for the 48 Fama and French industry groups and the interaction of industry and year effects, adjusting standard errors for industry clustering. This specification controls for clustering of mergers within industries over time (Andrade et al., 2001) and the possibility that mergers of late exercisers and their peers cluster in different waves. The effect on the results is negligible. 
4. CEO Preferences (Risk Tolerance; Inertia). Some CEOs may be more risk-tolerant than we assume in calibrating the CRRA utility function, or manage to hedge the risk of their options despite the prohibition of trading and short sales. These CEOs may delay option exercise and may also be inclined to undertake risky projects like mergers. However, absent other frictions, risk-neutral CEOs use first-best investment rules and the market should react positively to their merger bids. We find the opposite. Thus, risktolerance can explain the results only if (1) option-holding CEOs are risk-seeking; or (2) some other friction induces value-destroying mergers, and less risk-averse managers are more susceptible to it. Neither interpretation, though, predicts that such managers are more averse to stock financing (Section 5.1.) or more prone to undertake diversifying mergers (Section 5.2.1.).

Though not a preference-based explanation per se, variation in volatility could affect option exercise in the same way as variation in risk tolerance: higher volatility increases option value and induces later exercise. Moreover, acquisitiveness may increase stock volatility. Alternatively, CEOs in highly volatile firms may engage in mergers to diversify the corporate account (Amihud and Lev, 1981). Our results are robust to adding annual volatility as a control.

Late exercise may also be due to inertia in the sense of O'Donoghue and Rabin (2001). However, over $68 \%$ of Longholders conduct other transactions on their personal portfolios in the two years prior to the year their "longheld" options expire. Moreover, inertia cannot explain the link to increased merger frequency.

Finally, we test whether other CEO characteristics, which may capture individual preferences, drive both sub-optimal option exercise and excess acquisitiveness. We consider educational background, age, CEO tenure, and title accumulation (President and Chairman of the Board in addition to CEO). Tenure is a particularly important control given the correlation with Longholder (Table 2). We find that finance education has a positive impact on acquisitiveness, but is orthogonal to late exercise. The other CEO characteristics negatively impact the market reaction to merger bids, but do not affect the estimated impact of late exercise.

5. CEO Beliefs (Inside Information; Signaling). CEOs may delay option exercise because 
they believe that their stock will perform strongly and they want to profit personally from the expected appreciation. ${ }^{37}$ These beliefs may be correct: CEOs may have persistently positive inside information that their companies' stock is undervalued. Or, they may be incorrect: non-exercising CEOs are overconfident. In both cases, if the positive beliefs include potential mergers, they can link late exercise to merger decisions.

Several pieces of evidence help to distinguish information from overconfidence. If inside information drives late option exercise, the returns from holding the options should be positive. In Panel A of Table 7, we calculate the hypothetical returns that Longholder CEOs could have realized had they exercised their options one year before expiration and invested the proceeds in the S\&P 500. Allowing for maximum insider knowledge, we assume that both the hypothetical exercise and the actual exercise occur at the maximum stock price during the fiscal year. We find that, on average, Longholder CEOs did not profit from holding until expiration compared to this alternative strategy. The average return to exercising a year earlier is positive, though statistically insignificant. We also replicate the test for hypothetical exercise two, three, four, and five years before expiration. ${ }^{38}$ The average $\mathrm{CEO}$ would have done better under all four alternative strategies than by holding to expiration. Similarly, we calculate the hypothetical returns for Holder 67 CEOs from exercising in year five, when the options pass the $67 \%$ threshold, and investing the proceeds in the S\&P 500, rather than holding until the next year in which they exercise any options in the package. The mean difference in returns is -0.0049 with a standard deviation of 0.2997 . Thus, CEOs who delay option exercise do not earn abnormal returns over the S\&P 500 index on average, and the link between Longholder (or Holder 67) and mergers is unlikely due to inside information.

Nevertheless, we consider the possibility that some late exercise decisions reflect inside information and that these are precisely the cases that link to excessive merger activity. To address this possibility, we decompose Longholder into CEOs who profit from not

\footnotetext{
$\overline{37}$ As a rough measure of the stakes involved for the CEO, we multiply the current stock price times the number of options remaining in the package entering the expiration year. The average value is $\$ 5,465,086$.

${ }^{38}$ We increase the threshold for exercise by 0.05 per year earlier to account for the increase in the Hall-Murphy (2002) threshold as remaining duration on the option increases.
} 
exercising and CEOs who do not. The "winning" CEOs may indeed have positive inside information; the behavior of "losing" CEOs is more plausibly due to incorrect beliefs (overconfidence). We categorize Longholders into the group "Did OK" if, more often than not, they earned positive profits over the S\&P 500 by holding an option to expiration. The remaining Longholder CEOs are classified as "Should have exercised." We re-estimate Eq. (1) replacing Longholder with these two component variables. We find that the increased acquisitiveness of Longholders is not concentrated among the CEOs who profit from holding their options (Table 7, Panel B). To the contrary, only the coefficient of Longholders who "should have exercised" is significant. While the difference between the two groups is not significant ( $\mathrm{p}$-value $=0.14$ ), the significant effect of the loser group suffices to show that inside information cannot fully explain our results.

Finally, the Post-Longholder measure isolates differences in acquisitiveness among late-exercising CEOs which occur after their options expire. The disjoint timing of option-holding and mergers is difficult to reconcile with an information story since the information causing late exercise cannot be information about the merger itself. This measure also addresses the possibility that CEOs hold options to signal positive information about mergers. Signaling is unlikely to be effective for mergers occurring after the (held) options expire.

In summary, many potential explanations for the delay in option exercise do not affect our analysis since they do not predict increases in merger activity. Other theories make additional predictions that are not supported by the data. A third set of explanations can be accounted for directly in our merger regressions by including variables such as cash flow, stock returns, dividends, or volatility. Overconfidence, instead, is consistent with all of our evidence. ${ }^{39}$ It is important to stress, though, that our analysis does not rule out other determinants of option exercise. Rather, we argue that, after conducting the preceding tests and including a wide array of controls, the residual relation between late option exercise and mergers is most consistent with overconfidence.

\footnotetext{
${ }^{39}$ Alternatively, one may call a CEO who overinvests in his company and who does too many and bad mergers simply "stupid" or low-skilled. Since the managerial decisions point to systematic overestimation of future returns, overconfidence characterizes the type of the mistake more tightly.
} 
As a final test of the overconfidence interpretation, we introduce a second, mediabased proxy that is unlikely to be confounded by explanations like tax exposure and board pressure.

\subsection{Overconfidence and the press}

So far, we have used CEOs' personal portfolio decisions to identify differences in beliefs between managers and outsiders about the firms' future prospects. We now ask which CEOs outsiders perceive to be "confident" and "optimistic." Our proxy for market perception uses press coverage in leading business publications: The Wall Street Journal, The New York Times, BusinessWeek, Financial Times, and The Economist. This proxy provides direct insight into the type of person we classify as overconfident. While necessarily noisy and less precise than the portfolio measures, its strength is that it measures CEO beliefs as assessed by outsiders.

As described in Section 3, we retrieve all articles during the sample period that characterize sample CEOs as "Confident" (confident, confidence, optimistic, optimism) or "Cautious" (cautious, reliable, practical, conservative, frugal, steady, or negating one of the "Confident" terms). For all such articles, we determine (1) the article type, i.e., whether the article focuses on the CEO, the firm, or the market or industry as a whole, and (2) the source of the assessment, i.e., the identity of the person who characterized the CEO. We refine the article type for articles about the firm, which make up $80 \%$ of the sample, into articles mainly about a company product, earnings, mergers and acquisitions, company culture, or other firm events (e.g., lawsuits or financial policy). We perform both classifications separately on the subsamples of articles using "Confident" and "Cautious" terms. As a third step, we refine the Confident references and identify articles that attribute a high or excessive degree to the CEO.

The descriptive statistics (Panel A, Table 8) provide several important insights. First, the distribution of article types in the Confident and Cautious subsamples are similar, alleviating concerns that the articles in each subgroup focus on systematically different events. In particular, articles about mergers and acquisitions are not more likely for CEOs in the Confident category. Second, in $55 \%$ of the Confident articles the CEO 
himself expresses confidence, while only $30 \%$ of the Cautious articles are classified based on a CEO quote. Thus, the CEOs in the Confident group fit the image of outgoing and assertive managers. The majority of CEO characterizations, however, come from the journalist or other outsiders.

Finally, 21\% of the Confident articles describe the trait as "high" or "excessive." Many of these characterizations follow a big corporate decision (like a merger) with a bad outcome. Our empirical duration model eliminates this source of endogeneity since it excludes these articles from the analysis. Nevertheless, the statistic confirms that outsiders attribute excessive confidence or optimism to sample CEOs and often precisely as our theory would predict: following value-destroying acquisitions. ${ }^{40}$

To illustrate the typical context of Confident and Cautious mentions, we return to our example from Section 5.1., Wayne Huizenga of Blockbuster. Huizenga, a late option exerciser, is twice described as "optimistic" and once as "conservative." The first article is from The Wall Street Journal and falls into the "excessive confidence" category (Waldman, 1989). It discusses company stock performance amidst concerns about the company's accounting practices. The article notes that Huizenga "says he feels misunderstood" and uses optimism as follows:

"Mr. Huizenga remains ebullient in his optimism, determined to make life miserable for the "disbelievers" who have invested short in Blockbuster stock."

The second article, from BusinessWeek, uses the term "optimistic" with respect to Huizenga's projections of the spread of the VCR into American households (Engardio and Fins, 1989):

"With VCR sales tailing off, entertainment analyst Peter Ting of Richard Blum Associates believes even $80 \%$ penetration is optimistic."

The quotes are representative of the typical "confident" or "optimistic" reference: either the CEO expresses optimism about future company performance (often in the context of an earnings announcement) or an outsider assesses a CEO's forecast as optimistic.

The article using "conservative" appears four years later in BusinessWeek (DeGe-

$\overline{40}$ Thirty-seven percent of the "over-" confident mentions occur for CEOs who have already been described in prior sample years as "confident" or "optimistic." 
orge, 1993). It describes Huizenga's "ambitious plans to transform the ... video-rental giant into a full-scale entertainment company" through diversifying acquisitions. The article characterizes his approach to acquiring movie studios-first building up stakesas conservative. Generally, Cautious references apply to company strategy, though not always tied to a specific policy. ${ }^{41}$

To use this data in our merger analysis, we compare, for each year, the number of articles that refer to the CEO with $(a)$ the "Confident" terms and $(b)$ the "Cautious" terms or negated "Confident" terms. We then construct the following indicator for each CEO $i$ in year $t$ :

$$
\text { TOTALconfident }_{i t}=\left\{\begin{array}{l}
1 \text { if } \sum_{s=1}^{t-1} a_{i s}>\sum_{s=1}^{t-1} b_{i s} \\
0 \text { otherwise }
\end{array}\right.
$$

Like the Holder 67 measure, TOTALconfident captures not only between-firm and withinfirm variation in CEO types, but also variation within CEO. When using this measure, we control for the total number of press mentions over the same period (TOTALmentions), i.e., all sample years up to the previous year, ${ }^{42}$ since a press bias towards positive stories might imply a higher number of mentions as "confident" or "optimistic" when the total number of mentions is high.

Press coverage suffers from an important endogeneity problem: mergers may change the tenor of press coverage. The press may perceive acquiring CEOs as more confident, or managers may try to convey confidence during merger bids. Even though the descriptive statistics (Table 8, Panel A) alleviate this concern, we eliminate any remaining endogeneity by employing a duration model that restricts the sample to observations up to each CEO's first merger (if any). That is, we identify out of articles only up to the

${ }^{41}$ For the other examples of late exercisers in Section 5.1., we find four Confident articles and only one Cautious article for David Farrell and two Confident articles and one Cautious article for Reuben Mark. For the examples of CEOs not classified as late exercisers, we find two Confident and three Cautious articles in the case of J. Willard Marriott and no articles about Keith Crane. The context of the mentions follows the pattern described above.

${ }^{42}$ Alternatively, we calculate both TOTALconfident and TOTALmentions for the past year. 
year prior to the first merger. In addition, we drop executives who became CEO before the beginning of the sample period, for whom we cannot identify the first merger (and all press mentions during their tenure). The duration model tests whether press coverage as "optimistic" or "confident" shifts up the hazard for exiting the "no past mergers" state and includes dummy variables for each year prior to exit. We also address the concern that other personal characteristics may induce differential press coverage. We use handcollected data, described in Section 3, to control for educational background, age, and title accumulation (Chairman, President). Adding these additional controls reduces the sample size; thus, we report specifications with and without CEO-level controls.

Panel B of Table 8 displays the correlations of the press measures and the portfoliobased overconfidence measures. The correlations of TOTALconfident with Longholder and Holder 67 are positive (0.1 and 0.05, respectively) and statistically significant at the $1 \%$ level. Though the magnitudes appear low, it is important to note that the correlations are between noisy proxies for a managerial trait (overconfidence) that is not directly observable and are constructed from different data sources. For comparison, even the correlations between observable firm characteristics constructed from Compustat data are relatively low. The highest correlation (0.39) occurs between $Q$ and cash flow, two variables which both, at least partially, measure firm performance. As a placebo comparison, the correlations of the TOTALmentions control with the late-exercise measures are, instead, insignificant and near zero.

Panels C, D, and E display the correlations of TOTALconfident with various firm and CEO characteristics. As with the portfolio measures, there are few strong patterns. Unlike the portfolio measures, TOTALconfident is not correlated with vested option holdings. It is, however, strongly correlated with firm size, confirming the importance of the size control.

We repeat the analysis of merger frequency, substituting TOTALconfident for the portfolio measures and adapting the econometric specification to the duration model. Given the reduced sample size, we do not partition the sample based on internal resources and focus instead on the full sample tests. We find that CEOs portrayed as (net) "confident" and "optimistic" have 1.8 times higher odds of conducting their first 
merger at any point in time (Table 9). Controls for CEO characteristics increase the odds ratio to 2.5. Both estimates are significant, the latter at the $5 \%$ level. The odds ratio is similar in magnitude after including firm fixed effects, but the test is not sufficiently powerful (with only 371 identifiable observations and 79 firms) to reject the null hypothesis of a zero marginal effect. ${ }^{43}$

In Columns (3)-(6), we replicate the test of Prediction 2 from Section 5.2.1., using diversification as a proxy for negative expected value, in the duration framework. The odds ratios are 2.2 (no CEO controls) and 3.2 (with CEO controls) for diversifying mergers, significant at the 10 and 5\% levels, but 1.4 and 1.7 and insignificant for withinindustry mergers. Hence, TOTALconfident predicts heightened odds of exiting the "no merger" state by conducting a diversifying deal, but not by conducting an intra-industry merger.

To address the concern that "confident" press portrayal proxies for good past performance, we also re-estimate all regressions with controls for five lags of company stock returns. The results are unchanged and none of the return variables have consistent predictive power. As a further corroboration of the press measure, we note that it not only predicts acquisitiveness, but also investment-cash flow sensitivity. Malmendier and Tate (2005) show that similar portfolio measures of overconfidence predict heightened investment-cash flow sensitivity, particularly among equity-dependent firms. In untabulated results, we replicate these analyses with a simplified version of the TOTALconfident measure (calculated once for the full sample period).

These results corroborate the overconfidence explanation for mergers. Whether we measure differences in beliefs between the manager and the market using managerial portfolio decisions or press portrayal, the effect on merger activity is the same. Moreover, the press measure directly captures characterizations of executive personality features, providing insight into the type of executive identified by our portfolio measures

$\overline{43}$ The coefficient estimates for Vested Options are unstable and blow up when we add CEO controls. We therefore test for multicollinearity or extreme outliers driving the results. We find no evidence that the Vested Options control affects the TOTALconfident coefficient estimates. Similarly, the baseline hazards blow up in the within-industry, no-CEO-controls specification. This effect appears to arise from multicollinearity with the size variable. Excluding the size control, however, has no impact on the TOTALconfident coefficient estimate. 
of overconfidence.

\section{Conclusion}

We analyze the impact of overconfidence on merger decisions. Overconfidence does not necessarily predict more acquisitions-that depends on the trade-off between CEOs' perceived undervaluation of their company as a stand-alone and overestimation of future returns from acquisitions. However, absent other market frictions, overconfident CEOs are unambiguously more likely to make lower-quality acquisitions when their firm has abundant internal resources.

We measure overconfidence in two ways. First, we use CEOs' private investment decisions to capture their "revealed beliefs." Second, we use the press to measure outsiders' perceptions of the CEOs. Our empirical analysis confirms the overconfidence predictions. We also find that overconfident CEOs are more acquisitive unconditionally. Our results point to overconfidence as an important element of a unified theory of corporate mergers.

Much of the existing evidence in favor of the hubris hypothesis comes from interpreting the average announcement effects to merger bids: shareholders of target companies seem to gain while acquiring shareholders lose. However, these aggregate effects are open to many interpretations. A key contribution of our analysis is to directly measure which CEOs are prone to overconfidence (or hubris) and to show that those CEOs, in particular, destroy value for their shareholders through acquisitions. Our field evidence complements the vast experimental and psychological evidence on individual overconfidence.

Our results also have implications for contracting practices and organizational design. Overconfidence provides an alternative interpretation of agency problems in firms and of the origin of private benefits. Unlike CEOs with empire-building preferences, who consciously disregard shareholders' interests, overconfident CEOs believe they are maximizing value. Thus, standard incentive contracts are unlikely to correct their sub-optimal decisions. However, overconfident CEOs do respond to financing constraints. Overconfidence therefore further motivates the constraining role of capital structure. In addition, 
independent directors may need to play a more active role in project assessment and selection to counterbalance CEO overconfidence. 


\section{References}

Amihud, Y., Lev, B., 1981. Risk reduction as a managerial motive for conglomerate mergers. Bell Journal of Economics 12, 605-617.

Andrade, G., Mitchell, M., Stafford, E., 2001. New evidence and perspectives on mergers. Journal of Economic Perspectives 15, 103-120.

Asquith, P., 1983. Merger bids, uncertainty, and stockholder returns. Journal of Financial Economics 11, 51-83.

Baker, M., Ruback, R., Wurgler, J., 2006. Behavioral corporate finance: a survey. In: Eckbo, E. (Ed.), Handbook of Corporate Finance: Empirical Corporate Finance. North Holland, Amsterdam, pp. 145-186.

Baker, M., Stein, J., Wurgler, J., 2003. When does the market matter? Stock prices and the investment of equity-dependent firms. Quarterly Journal of Economics 118, 969-1006.

Barberis, N., Thaler, R., 2003. A survey of behavioral finance. In: Constantinides, G., Harris, M., Stulz, R. (Eds.), Handbook of the Economics of Finance: Financial Markets and Asset Pricing, North Holland, Amsterdam, pp. 1053-1124.

Berger, P., Ofek, E., 1995. Diversification's effect on firm value. Journal of Financial Economics 37, 39-66.

Bernardo, A., Welch, I., 2001. On the evolution of overconfidence and entrepreneurs. Journal of Economics and Management Strategy 10, 301-330.

Bradley, M., Desai, A., Kim, E., 1983. The rationale behind interfirm tender offers: information or synergy? Journal of Financial Economics 11, 183-206.

Camerer, C., Malmendier, U., 2007. Behavioral economics of organizations. In: Diamond, P., Vartiainen, H. (Eds.), Behavioral Economics and Its Applications, Princeton University Press, Princeton, NJ, pp. 235-290.

DeGeorge, G., 1993. Wayne's World: busting beyond video. Business Week 3343, 122.

Dodd, P., 1980. Merger proposals, managerial discretion and stockholder wealth. Journal of Financial Economics 8, 105-138.

Dong, M., Hirshleifer, D., Richardson, S., Teoh, S., 2006. Does investor misvaluation drive the takeover market? Journal of Finance 61, 725-762.

Dun \& Bradstreet Reference Book of Corporate Managements, 1997. Dun \& Bradstreet, Inc., Bethlehem, PA.

Engardio, P., Fins, A., 1989. Will this video chain stay on fast-forward? BusinessWeek 3109,72 . 
Fama, E., French, K., 2002. Testing tradeoff and pecking order predictions about dividends and debt. Review of Financial Studies 15, 1-33.

Firth, M., 1980. Takeovers, shareholder returns and the theory of the firm. Quarterly Journal of Economics 94, 235-260.

Goel, A., Thakor, A., 2000. Rationality, overconfidence and leadership, University of Michigan Business School Faculty Working Paper No. 00-022.

Gompers, P., Ishii, J., Metrick, A., 2003. Corporate governance and equity prices. Quarterly Journal of Economics 118, 107-155.

Graham, J., Lemmon, M., Wolf, J., 2002. Does corporate diversification destroy value? Journal of Finance 57, 695-720.

Guner, A., Malmendier, U., Tate, G., forthcoming. Financial expertise of directors. Journal of Financial Economics.

Hall, B., Liebman, J., 1998. Are CEOs really paid like bureaucrats? Quarterly Journal of Economics 113, 653-691.

Hall, B., Murphy, K., 2002. Stock options for undiversified executives. Journal of Accounting and Economics 33, 3-42.

Harford, J., 1999. Corporate cash reserves and acquisitions. Journal of Finance 54, 19691997.

Hayward, M., Hambrick, D., 1997. Explaining the premiums paid for large acquisitions: evidence of CEO hubris. Administrative Science Quarterly 42, 103-127.

Heaton, J. B., 2002. Managerial optimism and corporate finance. Financial Management $31,33-45$.

Jensen, M., 1986. Agency costs of free cash flow, corporate finance, and takeovers. American Economic Review (Papers \& Proceedings) 76, 323-329.

Jensen, M., 1988. Takeovers: their causes and consequences. Journal of Economic Perspectives 2, 21-48.

Jensen, M., Ruback, R., 1983. The market for corporate control: the scientific evidence. Journal of Financial Economics 11, 5-50.

Kaplan, S., Zingales, L., 1997. Do investment-cash flow sensitivities provide useful measures of financing constraints? Quarterly Journal of Economics 112, 169-215. 
Lambert, R., Larcker, D., Verrecchia, R., 1991. Portfolio considerations in valuing executive compensation. Journal of Accounting Research 29, 129-149.

Lamont, O., Polk, C., 2002. Does diversification destroy value? Evidence from industry shocks. Journal of Financial Economics, 63, 51-77.

Lamont, O., Polk, C., Saá-Requejo, J., 2001. Financial constraints and stock returns. Review of Financial Studies 14, 529-554.

Landier, A., Thesmar, D., 2003, Financial contracting with optimistic entrepreneurs: theory and evidence, New York University Working Paper.

Lang, L., Stulz, R., 1994. Tobin's Q, corporate diversification, and firm performance. Journal of Political Economy 102, 1248-1280.

Lang, L., Stulz, R., Walkling, R., 1989. Managerial performance, Tobin's Q, and the gains from successful tender offers. Journal of Financial Economics 24, 137-154.

Langer, E., 1975. The illusion of control. Journal of Personality and Social Psychology $32,311-328$.

Lys, T., Vincent, L., 1995. An analysis of value destruction in AT\&T's acquisition of NCR. Journal of Financial Economics 39, 353-378.

Malmendier, U., Tate, G., 2004. Who makes acquisitions? CEO overconfidence and the market's reaction. NBER Working Paper \#10807.

Malmendier, U., Tate, G., 2005. CEO overconfidence and corporate investment. Journal of Finance 60, 2661-2700.

March, J., Shapira, Z., 1987. Managerial perspectives on risk and risk taking. Management Science 33, 1404-1418.

Merton, R., 1973. Theory of rational option pricing. The Bell Journal of Economics and Management Science 4, 141-183.

Mitchell, M., Pulvino, T., Stafford, E., 2004. Price pressure around mergers. Journal of Finance 59, 31-63.

Moeller, S., Schlingemann, F., Stulz, R., 2005. Wealth destruction on a massive scale? A study of acquiring-firm returns in the recent merger wave. Journal of Finance 60, 757-782.

Morck, R., Shleifer, A., Vishny, R., 1990. Do managerial objectives drive bad acquisitions? Journal of Finance 45, 31-48.

Mulherin, J., Poulsen, A., 1998. Proxy contests and corporate change: implications for shareholder wealth. Journal of Financial Economics 47, 279-313. 
O’Donoghue, T., Rabin, M., 2001. Choice and procrastination. Quarterly Journal of Economics 116, 121-61.

Ofek, E., and Yermack, D., 2000. Taking stock: equity-based compensation and the evolution of managerial ownership. Journal of Finance 55, 1367-1384.

Roll, R., 1986. The hubris hypothesis of corporate takeovers. Journal of Business 59, 197-216.

Ruback, R., Mikkelson, W., 1984. Corporate investments in common stock. Proceedings of the Seminar on the Analysis of Security Prices 29, 179-209.

Schelling, T., 1960. The Strategy of Conflict. Harvard University Press, Cambridge, MA.

Schoar, A., 2002. Effects of corporate diversification on productivity. Journal of Finance $57,2379-2403$.

Servaes, H., 1991. Tobin's Q and the gains from takeovers. Journal of Finance 46, 409419.

Servaes, H., 1996. The value of diversification during the conglomerate merger wave. Journal of Finance 51, 1201-1225.

Seyhun, H., 1990. Do bidder managers knowingly pay too much for target firms? Journal of Business 63, 439-464.

Shefrin, H., 2000. Beyond greed and fear: understanding behavioral finance and the psychology of investing. Harvard Business School Press, Cambridge, MA.

Shleifer, A., Vishny, R., 2003. Stock market driven acquisitions. Journal of Financial Economics 70, 295-311.

Van den Steen, E., 2005. Organizations beliefs and managerial vision. Journal of Law, Economics, and Organization 21, 256-283.

Villalonga, B., 2004. Diversification discount or premium? New evidence from the business information tracking series. Journal of Finance 59, 479-506.

Waldman, P., 1989. Huizenga Says Blockbuster Won’t Bomb, The Wall Street Journal, May, 19, 1989.

Weinstein, N., 1980. Unrealistic optimism about future life events. Journal of Personality and Social Psychology 39, 806-820.

Weinstein, N., Klein, W., 2002. Resistance of personal risk perceptions to debiasing interventions. In: Gilovich, T., Griffin, D., Kahneman, D. (Eds.), Heuristics and Biases: The Psychology of Intuitive Judgment. Cambridge University Press, Cambridge, UK. 
Weston, J., Chung, K., Sui, J., 1998. Takeovers, Restructuring, and Corporate Governance. Prentice Hall, Upper Saddle River, NJ.

Who's Who in Finance and Industry, 1980/81-1995/96. Marquis Who's Who, Chicago, Ill.

Yermack, D., 1995. Do corporations award CEO stock options effectively? Journal of Financial Economics 39, 237-269. 


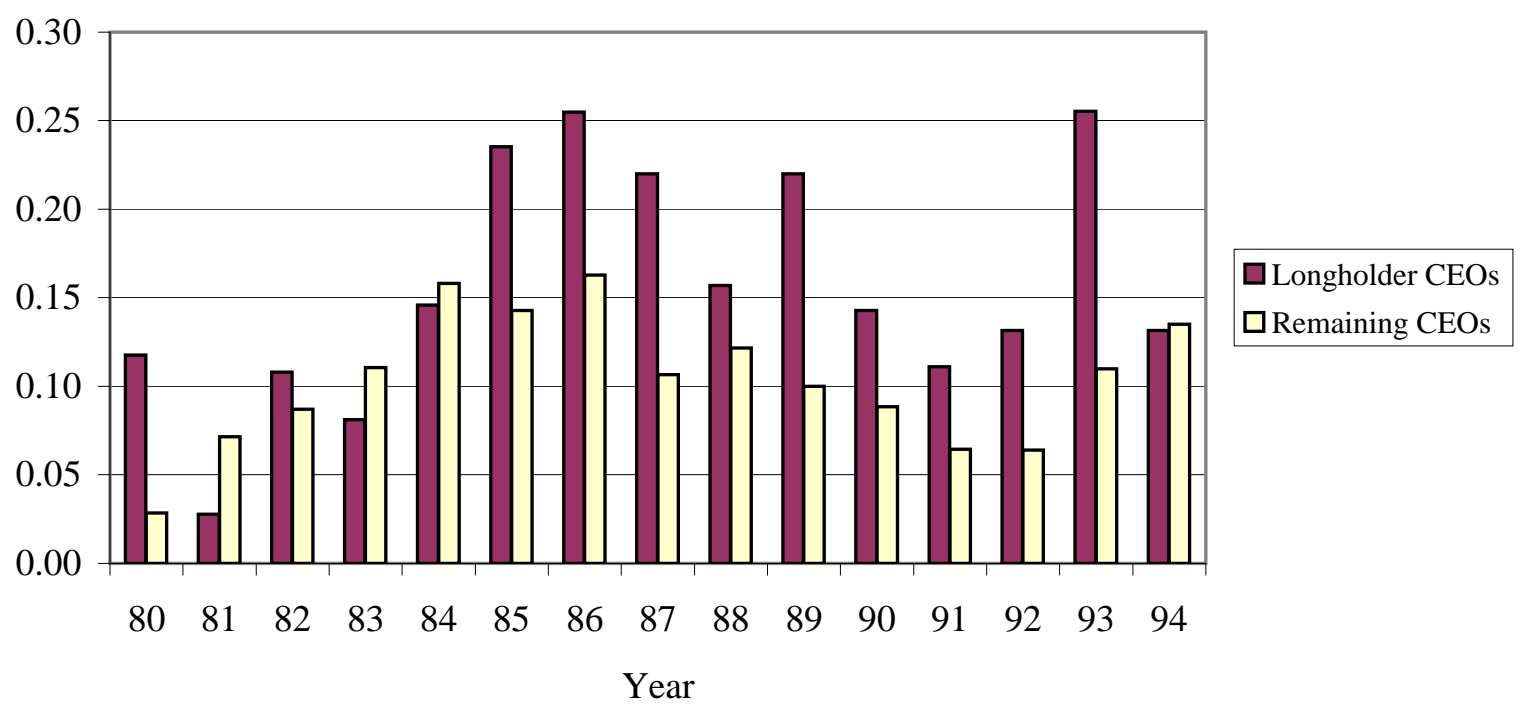

Fig. 1. Merger frequency (I): probability of completing a merger. The figure displays year-by-year merger frequencies, separately for Longholder CEOs and the remaining sample of CEOs. For each subgroup, the frequency is calculated as the number of CEOs who completed at least one merger divided by the total number of CEOs in that subgroup in a given year. Years are fiscal years.

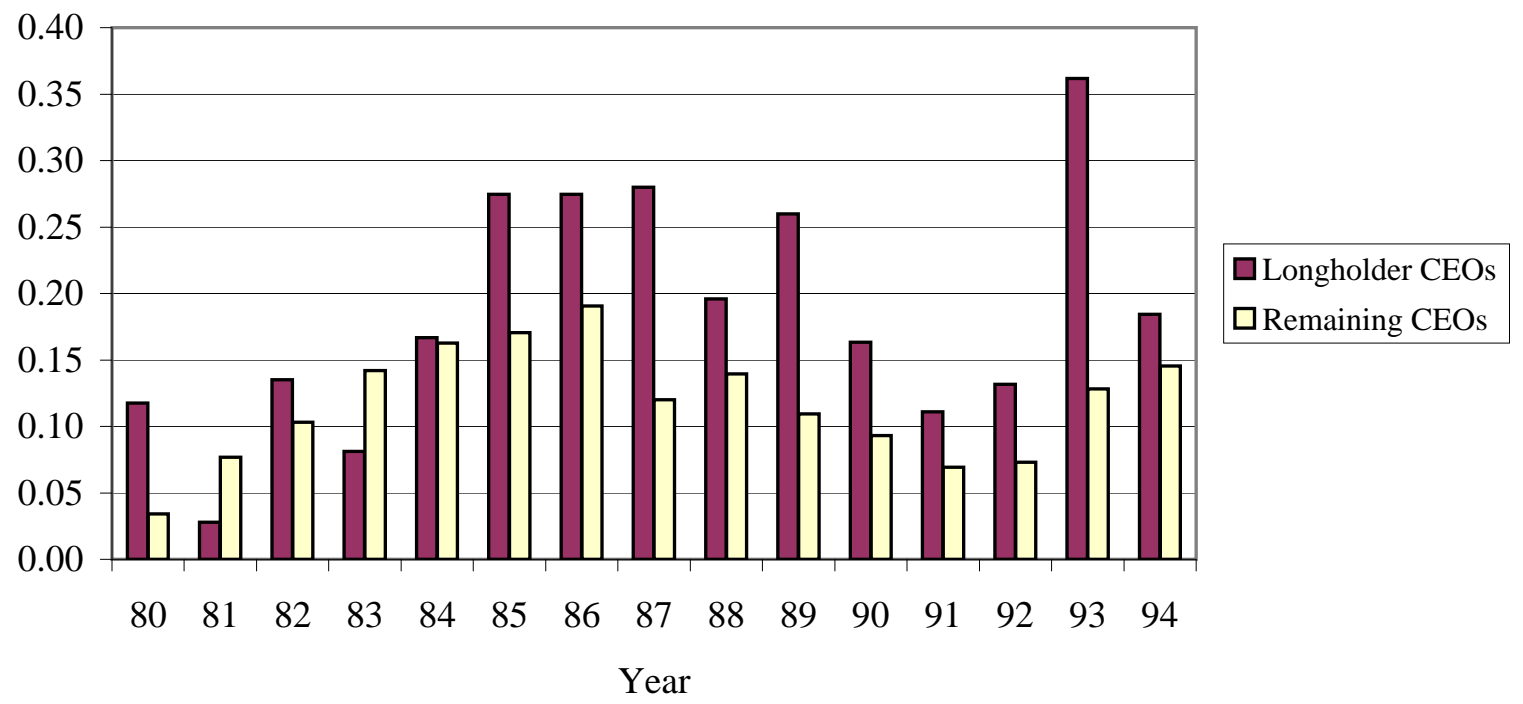

Fig. 2. Merger frequency (II): average number of mergers. The figure displays year-by-year merger frequencies, separately for Longholder CEOs and the remaining sample of CEOs. For each subgroup, the frequency is calculated as the number of mergers divided by the number of CEOs in that subgroup in a given year. Years are fiscal years. 
Table 1

Summary statistics

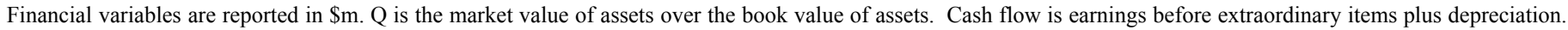

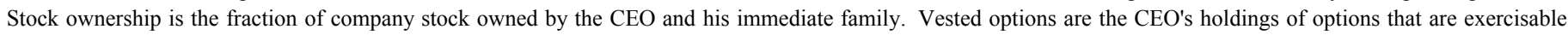

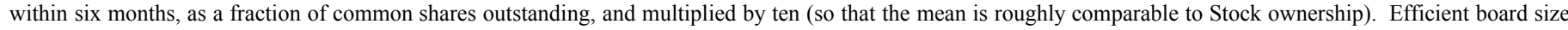

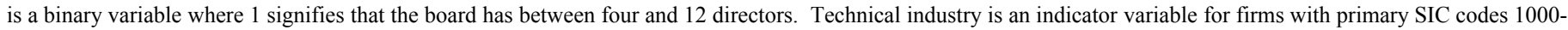

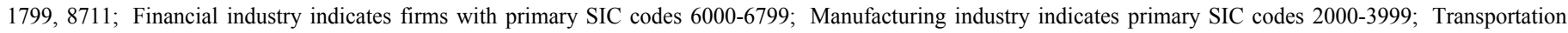

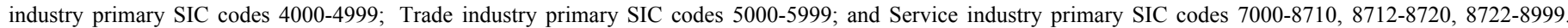

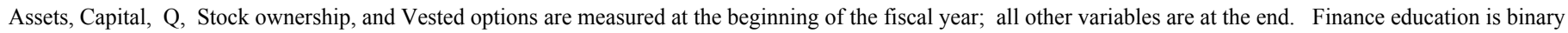

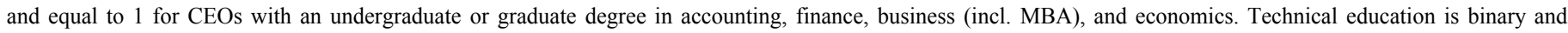

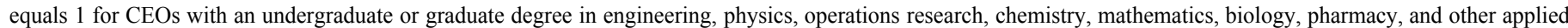

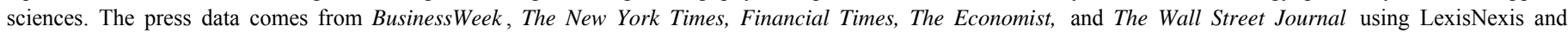

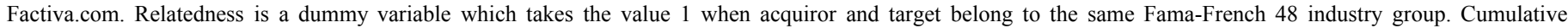

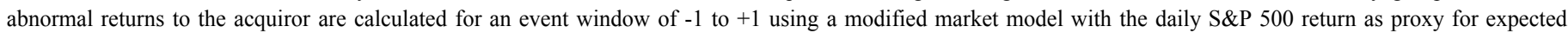
returns.

Panel A. Summary statistics of firm data

Full sample (394 firms)

\begin{tabular}{lrrrr}
\hline Assets & Obs. & Mean & Median & St. dev. \\
Capital (PPE) & 3,911 & $5,979.06$ & $2,248.15$ & $13,985.26$ \\
Investment (CAPX) & 3,911 & $2,278.64$ & 877.20 & $5,587.07$ \\
Cash flow & 3,704 & 385.00 & 153.44 & 952.94 \\
Cash flow normalized by lagged capital & 3,911 & 450.76 & 192.31 & 968.87 \\
Cash flow normalized by lagged assets & 3,911 & 0.37 & 0.26 & 0.36 \\
Q & 3,911 & 0.11 & 0.10 & 0.07 \\
Efficient board size & 3,911 & 1.42 & 1.12 & 0.88 \\
Technical industry & 3,911 & 0.55 & 1 & 0.50 \\
Manufacturing industry & 3,894 & 0.04 & 0 & 0.19 \\
Transportation industry & 3,894 & 0.48 & 0 & 0.50 \\
Trade industry & 3,894 & 0.24 & 0 & 0.43 \\
Financial industry & 3,894 & 0.10 & 0 & 0.31 \\
Service industry & 3,894 & 0.09 & 0 & 0.29 \\
\hline
\end{tabular}

Panel B. Summary statistics of CEO data

Full sample (738 CEOs)

Longholder CEOs (80 CEOs)

\begin{tabular}{|c|c|c|c|c|c|c|c|c|}
\hline 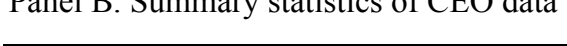 & Obs. & Mean & Median & St. dev. & Obs. & Mean & Median & St. dev. \\
\hline Age & 3,910 & 57.57 & 58 & 6.73 & 662 & 57.54 & 58 & 6.31 \\
\hline President and chairman & 3,911 & 0.38 & 0 & 0.48 & 662 & 0.36 & 0 & 0.48 \\
\hline Tenure & 3,873 & 8.50 & 6 & 7.39 & 639 & 10.68 & 9 & 7.07 \\
\hline Founder & 3,350 & 0.16 & 0 & 0.37 & 591 & 0.12 & 0 & 0.32 \\
\hline Stock ownership & 3,911 & 0.02 & 0.001 & 0.07 & 662 & 0.02 & 0.003 & 0.04 \\
\hline Vested options & 3,911 & 0.02 & 0.005 & 0.11 & 662 & 0.07 & 0.020 & 0.25 \\
\hline Finance education & 2,302 & 0.34 & 0 & 0.47 & 422 & 0.42 & 0 & 0.49 \\
\hline Technical education & 2,302 & 0.55 & 1 & 0.50 & 422 & 0.47 & 0 & 0.50 \\
\hline
\end{tabular}

Panel C. Summary statistics of CEO data

Full sample (393 firms, 738 CEOs)

\begin{tabular}{lrrrr} 
& Obs. & Mean & Median & St. dev. \\
\hline Total mentions & 3,889 & 8.89 & 3 & 22.03 \\
"Confident" mentions & 3,889 & 0.08 & 0 & 0.36 \\
"Optimistic" mentions & 3,889 & 0.07 & 0 & 0.32 \\
"Not confident" & 3,889 & 0.002 & 0 & 0.06 \\
"Not optimistic" & 3,889 & 0.004 & 0 & 0.07 \\
Reliable, cautious, conservative, practical, & 3,884 & 0.05 & 0 & 0.27 \\
$\quad$ steady, frugal" mentions & & & & \\
\hline & & & & \\
Panel D. Summary statistics of merger bids & Obs. & Mean & Median & St. dev. \\
\hline Relatedness & 808 & 0.386 & 0 & 0.487 \\
Cumulative abnormal return to acquiror [-1,+1] & 808 & -0.003 & -0.005 & 0.048 \\
Acquiror in technical industry & 808 & 0.026 & 0 & 0.159 \\
Acquiror in manufacturing industry & 808 & 0.314 & 0 & 0.465 \\
Acquiror in transportation industry & 808 & 0.099 & 0 & 0.299 \\
Acquiror in trade industry & 808 & 0.071 & 0 & 0.256 \\
Acquiror in financial industry & 808 & 0.444 & 0 & 0.497 \\
Acquiror in service industry & 808 & 0.046 & 0 & 0.209 \\
\hline
\end{tabular}


Table 2

\section{Correlations of portfolio measures}

Longholder is a binary variable where 1 signifies that the CEO at some point during his tenure held an option package until the last year before expiration, provided that the package was at least $40 \%$ in-the-money entering its last year. Size is the log of assets, Q the market value of assets over the book value of assets. Cash flow is earnings before extraordinary items plus depreciation, normalized by beginning-of-the-year capital. Stock ownership is the fraction of company stock owned by the CEO and his immediate family. Vested options are the CEO's holdings of options that are exercisable within six months, as a fraction of common shares outstanding, and multiplied by ten (so that the mean is roughly comparable to Stock ownership). Efficient board size is a binary variable equal to 1 if the board has between four and 12 directors. Size, Q, Stock ownership, and Vested options are measured at the beginning of the year; all other variables are at the end. Finance education is binary and equal to 1 for CEOs with an undergraduate or graduate degree in accounting, finance, business (incl. MBA), and economics. Technical education is binary and equals 1 for CEOs with an undergraduate or graduate degree in engineering, physics, operations research, chemistry, mathematics, biology, pharmacy, and other applied sciences.

Panel A. Correlations with firm characteristics $(N=3,911)$

\begin{tabular}{|c|c|c|c|c|c|c|c|}
\hline & Longholder & Size & $\mathrm{Q}$ & Cash flow & $\begin{array}{c}\text { Stock } \\
\text { ownership }\end{array}$ & $\begin{array}{l}\text { Vested } \\
\text { options }\end{array}$ & $\begin{array}{c}\text { Efficient } \\
\text { board size }\end{array}$ \\
\hline Longholder & 1 & & & & & & \\
\hline Size & -0.09 & 1 & & & & & \\
\hline Q & 0.09 & -0.32 & 1 & & & & \\
\hline Cash flow & 0.10 & -0.13 & 0.39 & 1 & & & \\
\hline Stock ownership & -0.04 & -0.18 & 0.10 & 0.11 & 1 & & \\
\hline Vested options & 0.19 & -0.17 & 0.09 & 0.17 & 0.10 & 1 & \\
\hline Efficient board size & 0.04 & -0.38 & 0.13 & 0.06 & 0.19 & 0.08 & 1 \\
\hline
\end{tabular}

Panel B. Correlations with CEO characteristics (I) $(N=3,872)$

\begin{tabular}{lcccc}
\hline & Longholder & Age & Pres. \& chm. & Tenure \\
\hline Longholder & 1 & & & \\
Age & 0.00 & 1 & & \\
President and chairman & -0.02 & -0.03 & 1 & \\
Tenure & 0.13 & 0.40 & 0.004 & 1 \\
\hline
\end{tabular}

Panel C. Correlations with CEO characteristics (II) $(N=2,078)$

\begin{tabular}{lccc}
\hline & Longholder & Fin. ed. & Tech. ed. \\
\hline Longholder & 1 & & \\
Finance education & 0.08 & 1 & \\
Technical education & -0.07 & -0.10 & 1 \\
\hline
\end{tabular}


Table 3

Do late exercisers complete more mergers?

The dependent variable is binary where 1 signifies that the firm made at least one merger bid that was eventually successful in a given year. Size is the log of assets, Q the market value of assets over the book value of assets. Cash flow is earnings before extraordinary items plus depreciation, normalized by beginning-of-the-year capital. Stock ownership is the fraction of company stock owned by the CEO and his immediate family. Vested options are the CEO's holdings of options that are exercisable within six months, as a fraction of common shares outstanding, and multiplied by ten (so that the mean is roughly comparable to Stock ownership). Efficient board size is a binary variable where 1 signifies that the board of directors has between four and 12 members. Longholder is a binary variable where 1 signifies that the CEO at some point during his tenure held an option package until the last year before expiration, provided that the package was at least $40 \%$ in-the-money entering its last year. Post-longholder is a dummy equal to 1 for all CEO-years after the CEO for the first time holds options to expiration. Pre-longholder are all years classified as 1 under Longholder, but 0 under Post-longholder. Holder 67 is a dummy equal to 1 for all CEO years after the CEO for the first time fails to exercise a $67 \%$ in-the-money option with five years remaining duration. In the Holder 67 regressions, the sample is limited to CEO years after the CEO for the first time had a $67 \%$ in-the-money option with five years remaining duration. Size, Q, Stock ownership, and Vested options are measured at the beginning of the year; all other variables are at the end. The fixed-effects logit model is estimated consistently using a conditional logit specification and standard errors are robust to heteroskedasticity and arbitrary within-firm serial correlation. In Columns (4) - (6), we use the cash-reserves model of Harford (1999) to identify cash-rich and cash-poor firms. In the untabulated first stage, we regress cash and short-term investments scaled by (net) sales on the following independent variables: net cash flow to sales, defined as operating cash flow (operating income before depreciation - interest - taxes - $\Delta$ non-cash working capital) minus investment (capital expenditures) over sales; risk premium, defined as the spread in interest rates between AAA and Baa bonds, measured in the month the fiscal year ends; NBER recession, defined as an indicator variable for fiscal years that end within an NBER-defined recession; Q, defined as the market value of assets over the book value of assets; cash flow volatility, defined as the coefficient of variation of firm-specific operating cash flows; and size, defined as the market value of the firm (fiscal-year end stock-price times common shares outstanding). Column (4) shows the results of the random-effects estimation on the full sample of firm-years, for which all variables of the Harford (1998) cash-reserves model are available. Column (5) shows the results for the subsample of Cash-rich firm-years, in which cash reserves at the beginning of the year are at least 1.5 standard deviations above the predicted value from the first-stage cash-reserves regression. The relevant standard deviation is the firm-specific standard deviation of cash reserves. Column (6) contains the random-effects estimation for the remaining subsample of Cash-poor firm-years. All coefficients are presented as odds ratios.

\begin{tabular}{|c|c|c|c|c|c|c|}
\hline & \multicolumn{3}{|c|}{ Fixed-effects logit } & \multicolumn{3}{|c|}{ Random-effects logit } \\
\hline & (1) & (2) & (3) & $\begin{array}{c}\text { Baseline } \\
\text { (4) }\end{array}$ & $\begin{array}{c}\text { Cash rich } \\
\text { (5) }\end{array}$ & $\begin{array}{c}\text { Cash poor } \\
\text { (6) }\end{array}$ \\
\hline \multirow[t]{2}{*}{ Size } & 0.6537 & 0.6600 & 0.3278 & 0.9022 & 0.9480 & 0.9177 \\
\hline & $(2.50)^{* *}$ & $(2.42)^{* *}$ & $(3.42)^{* * *}$ & $(1.49)$ & $(0.50)$ & $(1.03)$ \\
\hline \multirow[t]{2}{*}{ Q } & 0.7135 & 0.7154 & 0.9062 & 0.7019 & 0.7686 & 0.6839 \\
\hline & $(2.20) * *$ & $(2.18) * *$ & $(0.45)$ & $(2.96)^{* * *}$ & $(1.25)$ & $(2.70) * * *$ \\
\hline \multirow[t]{2}{*}{ Cash flow } & 2.0231 & 2.0377 & 1.6607 & 1.5427 & 0.9948 & 1.8719 \\
\hline & $(1.72)^{*}$ & $(1.72)^{*}$ & $(0.67)$ & $(2.07)^{* *}$ & $(0.01)$ & $(2.35)^{* *}$ \\
\hline \multirow[t]{2}{*}{ Stock ownership } & 0.3840 & 0.3813 & 0.0418 & 1.4084 & 21.4335 & 0.7232 \\
\hline & $(0.95)$ & $(0.96)$ & $(0.70)$ & $(0.36)$ & $(1.80)^{*}$ & $(0.29)$ \\
\hline \multirow[t]{2}{*}{ Vested options } & 0.4566 & 0.4595 & 0.6384 & 1.2165 & 4.2168 & 1.3186 \\
\hline & $(3.97)^{* * *}$ & $(3.93)^{* * *}$ & $(0.51)$ & $(0.46)$ & $(0.91)$ & $(0.63)$ \\
\hline \multirow[t]{2}{*}{ Efficient board size } & 1.0817 & 1.0811 & 1.8488 & 0.8012 & 0.575 & 0.9184 \\
\hline & $(0.40)$ & $(0.40)$ & $(2.10)^{* *}$ & $(1.55)$ & $(2.44)^{* *}$ & $(0.48)$ \\
\hline \multirow[t]{2}{*}{ Longholder } & 2.1891 & & & 1.7447 & 1.9728 & 1.5471 \\
\hline & $(2.70)^{* * *}$ & & & $(3.21)^{* * *}$ & $(2.53)^{* *}$ & $(2.10)^{* *}$ \\
\hline \multirow[t]{2}{*}{ Post-longholder } & & 1.8642 & & & & \\
\hline & & $(1.91)^{*}$ & & & & \\
\hline \multirow[t]{2}{*}{ Pre-longholder } & & 2.3305 & & & & \\
\hline & & $(2.72)^{* * *}$ & & & & \\
\hline \multirow[t]{2}{*}{ Holder 67} & & & 2.5159 & & & \\
\hline & & & $(2.49)^{* *}$ & & & \\
\hline Firm fixed effects & yes & yes & yes & no & no & no \\
\hline Year fixed effects & yes & yes & yes & yes & yes & yes \\
\hline Observations & 2,568 & 2,568 & 853 & 3,540 & 1,227 & 2,313 \\
\hline Number of firms & 225 & 225 & 124 & 322 & 282 & 314 \\
\hline
\end{tabular}

z-statistics in parentheses. Constant included.

$*$ significant at $10 \% ; * *$ significant at $5 \% ; * *$ significant at $1 \%$. 
Table 4

\section{Merger financing}

The sample includes all successful merger bids. The dependent variable in Panel B is binary and equals 1 if the merger was financed using only cash. Q below industry is a binary variable where 1 indicates that $\mathrm{Q}$ at the beginning of the year was less than or equal to industry $\mathrm{Q}$. Industries are the 48 Fama-French industry groups. $\mathrm{Q}$ is the market value of assets over the book value of assets. Stock ownership is the fraction of company stock owned by the CEO and his immediate family. Vested options are the CEO's holdings of options that are exercisable within six months, as a fraction of common shares outstanding, and multiplied by ten (so that the mean is roughly comparable to Stock ownership). Merger size is the amount the acquiror paid for the target as a fraction of acquiror value (for SDC mergers, amount paid is the value of the transaction; for CRSP mergers, it is the market value of the target the day after the announcement. When both variables are present, we use the minimum). Cash rich is a dummy variable equal to 1 if cash reserves at the beginning of the year are at least 1.5 standard deviations above the predicted value from the cash reserves regression. The relevant standard deviation is the firm-specific standard deviation of cash reserves. In the cash-reserves regression (which follows Harford, 1999), we regress cash and short-term investments scaled by (net) sales on the following independent variables: net cash flow to sales, defined as operating cash flow (operating income before depreciation - interest - taxes - $\Delta$ non-cash working capital) minus investment (capital expenditures) over sales; risk premium, defined as the spread in interest rates between AAA and Baa bonds, measured in the month the fiscal year ends; NBER recession, defined as an indicator variable for fiscal years that end within an NBER-defined recession; Q, defined as the market value of assets over the book value of assets; cash flow volatility, defined as the coefficient of variation of firm-specific operating cash flows; and size, defined as the market value of the firm (fiscal-year end stock-price times common shares outstanding). Longholder is a binary variable where 1 signifies that the CEO at some point during his tenure held an option package until the last year before expiration, provided that the package was at least $40 \%$ in-the-money entering its last year. Q below industry, Q, Stock ownership, Vested options, and Cash rich are measured at the beginning of the year; all other variables are at the end. Standard errors are robust to heteroskedasticity and arbitrary within-firm serial correlation. Coefficients are presented as odds ratios.

Panel A. All mergers with disclosed method of payment

\begin{tabular}{|c|c|c|c|c|c|c|c|c|c|}
\hline & $\begin{array}{c}\text { Total } \\
\text { mergers }\end{array}$ & Cash & $\begin{array}{c}\text { Debt OR } \\
\text { cash and } \\
\text { debt }\end{array}$ & $\begin{array}{c}\text { Stock } \\
\text { AND cash } \\
\text { and/or } \\
\text { debt }\end{array}$ & Stock & $\begin{array}{c}\text { odds } \\
\text { (cash v. } \\
\text { stock) }\end{array}$ & $\begin{array}{c}\text { odds } \\
\text { (cash v. } \\
\text { other) }\end{array}$ & $\begin{array}{l}\text { odds ratio } \\
\text { (v. stock) }\end{array}$ & $\begin{array}{l}\text { odds ratio } \\
\text { (v. other) }\end{array}$ \\
\hline Longholder $=1$ & 188 & $38.8 \%$ & $6.9 \%$ & $19.7 \%$ & $34.6 \%$ & 1.12 & 0.63 & 1.09 & 1.10 \\
\hline Longholder $=0$ & 708 & $33.5 \%$ & $8.3 \%$ & $25.6 \%$ & $32.6 \%$ & 1.03 & 0.58 & & \\
\hline
\end{tabular}

Panel B. Logit regressions

\begin{tabular}{lccccc}
\hline & $(1)$ & $(2)$ & $(3)$ & $(4)$ & $(5)$ \\
\hline Q below industry & & 1.7215 & 1.8457 & 1.9274 & 1.1035 \\
Q & & $(2.72)^{* * *}$ & $(3.02)^{* * *}$ & $(3.11)^{* * *}$ & $(0.39)$ \\
& 0.8018 & & 1.2618 & 1.0288 & 0.6457 \\
Stock ownership & $(1.28)$ & & $(1.26)$ & $(0.14)$ & $(1.90)^{*}$ \\
& 2.818 & & 1.7263 & 1.6837 & 0.1726 \\
Vested options & $(0.87)$ & & $(0.41)$ & $(0.42)$ & $(1.30)$ \\
& 0.3403 & & 0.5818 & 0.4279 & 0.2214 \\
Merger size & $(1.54)$ & & $(0.75)$ & $(1.21)$ & $(1.04)$ \\
& 0.9934 & & 0.981 & 0.9927 & 0.9924 \\
Cash rich & $(0.58)$ & & $(1.37)$ & $(0.58)$ & $(0.73)$ \\
& & & & & 1.3895 \\
Longholder & & & & & $(1.55)$ \\
& 1.2001 & 0.7423 & 0.7685 & 0.7766 & 0.8383 \\
(Q below industry)*(Longholder) & $(0.77)$ & $(0.84)$ & $(0.76)$ & $(0.72)$ & $(0.45)$ \\
& & 2.3096 & 2.2577 & 1.9555 & 2.0647 \\
Year fixed effects & & $(2.09)^{* *}$ & $(2.06)^{* *}$ & $(1.71)^{*}$ & $(1.67)^{*}$ \\
\hline Observations & yes & no & no & yes & yes \\
\hline
\end{tabular}

z-statistics in parentheses. Constant included.

* significant at $10 \% ; * *$ significant at $5 \% ; * * *$ significant at $1 \%$. 
Table 5

Diversifying and same-industry mergers

The dependent variable in Panel 1 (Panel 2) is binary where 1 signifies that the firm made a diversifying (within-industry) merger bid that was eventually successful in a given year. Diversification is measured using the 48 Fama and French industry groups. Size is the log of assets, Q the market value of assets over the book value of assets. Cash flow is earnings before extraordinary items plus depreciation, normalized by beginning-of-the-year capital. Stock ownership is the fraction of company stock owned by the CEO and his immediate family. Vested options are the CEO's holdings of options that are exercisable within six months, as a fraction of common shares outstanding, and multiplied by ten (so that the mean is roughly comparable to Stock ownership). Efficient board size is a binary variable where 1 signifies that the board of directors has between four and 12 members. Longholder is a binary variable where 1 signifies that the CEO at some point during his tenure held an option package until the last year before expiration, provided that the package was at least $40 \%$ in-the-money entering its last year. Size, Q, Stock ownership, and Vested options are measured at the beginning of the year; all other variables are at the end. The fixed-effects logit model is estimated consistently using a conditional logit specification, and standard errors are robust to heteroskedasticity and arbitrary within-firm serial correlation. The random-effects estimations employ the cash-reserves model of Harford (1999) to identify cash-rich and cash-poor firms. In the untabulated first stage, we regress cash and short-term investments scaled by (net) sales on the following independent variables: net cash flow to sales, defined as operating cash flow (operating income before depreciation - interest - taxes - $\Delta$ non-cash working capital) minus investment (capital expenditures) over sales; risk premium, defined as the spread in interest rates between AAA and Baa bonds, measured in the month the fiscal year ends; NBER recession, defined as an indicator variable for fiscal years that end within an NBER-defined recession; Q, defined as the market value of assets over the book value of assets; cash flow volatility, defined as the coefficient of variation of firm-specific operating cash flows; and size, defined as the market value of the firm (fiscal-year end stock-price times common shares outstanding). The baseline estimation uses the full sample of firm-years, for which all variables of the Harford cash reserves model are available. The Cash-rich subsample contains all firm-years in which actual cash reserves at the beginning of the year are at least 1.5 standard deviations above the predicted value from the baseline cash reserves regression. The relevant standard deviation is the firm-specific standard deviation of cash reserves. The Cash-poor subsample contains all remaining firm-years. All coefficients are presented as odds ratios.

\begin{tabular}{|c|c|c|c|c|}
\hline & Fixed-effects logit & & lom-effects & \\
\hline & & Baseline & Cash rich & Cash poor \\
\hline Panel 1. Diversifyin & & & & \\
\hline Size & 0.7592 & 1.065 & 1.1462 & 1.0689 \\
\hline & $(1.29)$ & $(0.73)$ & $(0.95)$ & $(0.64)$ \\
\hline Q & 0.8437 & 0.718 & 0.7241 & 0.7092 \\
\hline & $(0.86)$ & $(2.08)^{* *}$ & $(1.05)$ & $(1.87)^{*}$ \\
\hline Cash flow & 2.1685 & 1.5963 & 0.8767 & 2.0797 \\
\hline & $(1.53)$ & $(1.84)^{*}$ & $(0.28)$ & $(2.32) * *$ \\
\hline Stock ownership & 0.1268 & 2.5704 & 98.2692 & 1.2053 \\
\hline & $(1.48)$ & $(0.81)$ & $(2.10)^{* *}$ & $(0.13)$ \\
\hline Vested options & 0.8589 & 1.5657 & 4.3008 & 1.6552 \\
\hline & $(0.50)$ & $(1.01)$ & $(0.54)$ & $(1.11)$ \\
\hline Efficient board size & 0.9737 & 0.7331 & 0.4504 & 0.8741 \\
\hline & $(0.11)$ & $(1.71)^{*}$ & $(2.62)^{* * *}$ & $(0.60)$ \\
\hline Longholder & 2.5376 & 2.0108 & 2.5042 & 1.781 \\
\hline & $(3.31)^{* * *}$ & $(3.29)^{* * *}$ & $(2.56)^{* *}$ & $(2.27)^{* *}$ \\
\hline Firm fixed effects & yes & no & no & no \\
\hline Year fixed effects & yes & yes & yes & yes \\
\hline Observations & 1,832 & 3,540 & 1,227 & 2,313 \\
\hline Number of firms & 159 & 322 & 282 & 314 \\
\hline Panel 2. Within-ind & & & & \\
\hline Size & 0.4656 & 0.6992 & 0.7031 & 0.7302 \\
\hline & $(2.77)^{* * *}$ & $(3.42)^{* * *}$ & $(2.40)^{* *}$ & $(2.45)^{* *}$ \\
\hline Q & 0.5359 & 0.6864 & 0.7664 & 0.6572 \\
\hline & $(2.43)^{* *}$ & $(2.23)^{* *}$ & $(1.02)$ & $(2.02)^{* *}$ \\
\hline Cash flow & 2.496 & 1.3048 & 1.096 & 1.483 \\
\hline & $(1.50)$ & -0.84 & $(0.20)$ & $(0.94)$ \\
\hline Stock ownership & 0.8916 & 0.819 & 1.1449 & 0.6252 \\
\hline & $(0.10)$ & $(0.14)$ & $(0.06)$ & $(0.30)$ \\
\hline Vested options & 0.1853 & 0.6936 & 3.6528 & 0.7161 \\
\hline & $(3.71)^{* * *}$ & $(0.66)$ & $(0.78)$ & $(0.54)$ \\
\hline Efficient board size & 1.1113 & 0.844 & 0.7228 & 0.9176 \\
\hline & $(0.36)$ & $(0.82)$ & $(1.11)$ & $(0.33)$ \\
\hline Longholder & 1.6646 & 1.2965 & 1.3161 & 1.1471 \\
\hline & $(1.03)$ & $(1.01)$ & $(0.82)$ & $(0.43)$ \\
\hline Firm fixed effects & yes & no & no & no \\
\hline Year fixed effects & yes & yes & yes & yes \\
\hline Observations & 1,467 & 3,540 & 1,227 & 2,313 \\
\hline Number of firms & 127 & 322 & 282 & 314 \\
\hline
\end{tabular}

Z-statistics in parentheses. Constant included.

* significant at $10 \% ; *$ significant at $5 \% ; * *$ significant at $1 \%$. 
Table 6

\section{Market response}

The event window is from the day before through the day after the announcement of the bid. The dependent variable in Panel $\mathrm{B}$ is the Cumulative abnormal return on the bidder's stock from the day before the announcement of the bid through the day after. Cumulative abnormal returns are calculated by taking the daily return on the bidder's common equity and subtracting expected returns. Expected returns are the daily return on the S\&P 500 index. Cash bids are financed with any combination of cash and debt. Stock bids are financed with any portion of equity. Stock ownership is the fraction of company stock owned by the CEO and his immediate family at the beginning of the year in which the bid occurs. Vested options are the CEO's holdings of options that are exercisable within six months of the beginning of the year of the bid, as a fraction of common shares outstanding, and multiplied by ten (so that the mean is roughly comparable to Stock ownership). Relatedness is 1 for acquisitions in which the bidder and target firms are in the same industry, measured using the 48 Fama and French industry groups. Cash financing is a binary variable where 1 indicates that the acquisition was financed using some combination of cash and debt. Efficient board size is a binary variable where 1 signifies that the board of directors has between four and 12 members. Longholder is a binary variable where 1 signifies that the CEO at some point during his tenure held an option until the last year before expiration, provided that the package was at least $40 \%$ in-the-money entering its last year. Postlongholder is a dummy equal to 1 for all CEO-years after the CEO for the first time holds options to expiration. Prelongholder are all years classified as 1 under Longholder, but 0 under Post-longholder. All standard errors in Panel B are clustered by event date to account for cross-sectional correlation of stock returns.

Panel A.

\begin{tabular}{llll}
\hline & \multicolumn{3}{c}{ Average CAR [-1,+1] } \\
& All bids & Cash bids & Stock bids \\
\hline Full sample & -0.0029 & 0.0045 & -0.0087 \\
& $(808 ; 1.73)^{*}$ & $(354 ; 1.82)^{*}$ & $(454 ; 3.94)^{* * *}$ \\
Longholder $=0$ & -0.0012 & 0.0070 & -0.0075 \\
Longholder $=1$ & $(611 ; 0.62)$ & $(265 ; 2.21)^{* *}$ & $(346 ; 3.03)^{* * * *}$ \\
& -0.0090 & -0.0032 & -0.0135 \\
Pre-longholder $=1$ & $(178 ; 2.73)^{* * *}$ & $(78 ; 0.88)$ & $(100 ; 2.64)^{* * * *}$ \\
& & & \\
Post-longholder $=1$ & -0.0052 & -0.0033 & -0.0066 \\
& $(115 ; 1.26)$ & $(48 ; 0.81)$ & $(67 ; 1.02)$ \\
& -0.0160 & -0.0031 & -0.0277 \\
& $(63 ; 2.91)^{* * *}$ & $(30 ; 0.45)$ & $(33 ; 3.49)^{* * *}$ \\
\hline
\end{tabular}

Number of observations and t-statistics in parentheses.

Panel B. OLS Regressions

\begin{tabular}{|c|c|c|c|c|c|}
\hline & (1) & $(2)$ & (3) & $(4)$ & $(5)$ \\
\hline \multirow[t]{2}{*}{ Stock ownership } & & 0.052 & 0.0561 & 0.051 & 0.0555 \\
\hline & & $(1.41)$ & $(1.51)$ & $(1.39)$ & $(1.49)$ \\
\hline \multirow[t]{2}{*}{ Vested options } & & 0.1039 & 0.1071 & 0.105 & 0.1066 \\
\hline & & $(2.64)^{* * *}$ & $(2.59)^{* * *}$ & $(2.65)^{* * *}$ & $(2.58)^{* *}$ \\
\hline \multirow[t]{2}{*}{ (Vested options) $^{2}$} & & -0.0322 & -0.0329 & -0.033 & -0.0332 \\
\hline & & $(2.67)^{* * *}$ & $(2.59)^{* * *}$ & $(2.72)^{* * *}$ & $(2.62)^{* * *}$ \\
\hline \multirow[t]{2}{*}{ Relatedness } & & 0.0035 & 0.0034 & 0.0039 & 0.0037 \\
\hline & & $(1.02)$ & $(0.98)$ & $(1.13)$ & $(1.07)$ \\
\hline \multirow[t]{2}{*}{ Efficient board size } & & 0.0053 & 0.0058 & 0.0056 & 0.006 \\
\hline & & $(1.31)$ & $(1.42)$ & $(1.38)$ & $(1.47)$ \\
\hline \multirow[t]{2}{*}{ Cash financing } & & 0.0119 & 0.0155 & 0.0119 & 0.0155 \\
\hline & & $(3.39)^{* * *}$ & $(4.03)^{* * *}$ & $(3.41)^{* * *}$ & $(4.02)^{* * *}$ \\
\hline \multirow[t]{2}{*}{ Longholder } & -0.0078 & -0.0112 & -0.0115 & & \\
\hline & $(2.02)^{* *}$ & $(2.72)^{* * *}$ & $(2.80)^{* * *}$ & & \\
\hline \multirow[t]{2}{*}{ Post-longholder } & & & & -0.0198 & -0.0193 \\
\hline & & & & $(3.46)^{* * *}$ & $(3.29)^{* * *}$ \\
\hline \multirow[t]{2}{*}{ Pre-longholder } & & & & -0.0065 & -0.007 \\
\hline & & & & $(1.34)$ & $(1.50)$ \\
\hline Year fixed effects & no & no & yes & no & yes \\
\hline Observations & 789 & 789 & 789 & 789 & 789 \\
\hline $\mathrm{R}^{2}$ & 0.00 & 0.05 & 0.08 & 0.06 & 0.08 \\
\hline
\end{tabular}

t-statistics in parentheses. Constant included.

* significant at 10\%; ** significant at 5\%; *** significant at $1 \%$. 
Table7

Are Longholders right to hold their options?

In Panel A, we calculate the return the CEO would have earned from exercising the option one year earlier and investing in the S\&P 500 for each option that is held until expiration and that is at least $40 \%$ in-the-money at the beginning of its final year. We assume exercise both in the final year and in the hypothetical year occur at the maximum stock price during that year. In Panel B, the dependent variable is binary where 1 signifies that the firm made at least one merger bid that was eventually successful in a given year. Size is the log of assets, Q the market value of assets over the book value of assets. Cash flow is earnings before extraordinary items plus depreciation, normalized by beginning-of-the-year capital. Stock ownership is the fraction of company stock owned by the CEO and his immediate family. Vested options are the CEO's holdings of options that are exercisable within six months, as a fraction of common shares outstanding, and multiplied by ten (so that the mean is roughly comparable to Stock ownership). Efficient board size is a binary variable where 1 signifies that the board of directors has between four and 12 members. Longholder is a binary variable where 1 signifies that the $\mathrm{CEO}$ at some point during his tenure held an option package until the last year before expiration, provided that the package was at least $40 \%$ in the money entering its last year. Longholder: did OK is 1 for CEOs for whom Longholder is 1 and who did better by holding at least as many times as they would have done better by exercising longheld options a year earlier and investing in the S\&P 500 . Longholder: should have exercised is 1 for CEOs for whom Longholder is 1 and who would have done better by exercising a year earlier more times than they did better by holding. Size, Q, Stock ownership, and Vested options are measured at the beginning of the year; all other variables are at the end. The fixed-effects logit model is estimated consistently using a conditional logit specification. Standard errors are robust to heteroskedasticity and arbitrary within-firm serial correlation. Coefficients are presented as odds ratios.

Panel A. Returns to diversifying

\begin{tabular}{rc}
\hline Percentile & Return \\
\hline 10 th & -0.24 \\
20 th & -0.15 \\
30 th & -0.10 \\
40 th & -0.05 \\
50 th & -0.03 \\
60 th & 0.03 \\
70 th & 0.10 \\
80 th & 0.19 \\
90 th & 0.39 \\
\hline Mean & 0.03 \\
St. dev. & 0.27 \\
\hline
\end{tabular}

Panel B. Do "mistaken" holders drive the acquisitiveness result?

\begin{tabular}{lc}
\hline & Fixed-effects logit \\
\hline Size & 0.6757 \\
& $(2.20)^{* *}$ \\
& 0.7147 \\
Cash flow & $(2.14)^{* *}$ \\
& 2.052 \\
Stock ownership & $(1.71)^{*}$ \\
& 0.3502 \\
Vested options & $(0.97)$ \\
& 0.3026 \\
Efficient board size & $(1.03)$ \\
& 1.111 \\
Longholder: did OK & $(0.54)$ \\
& 1.4259 \\
Longholder: should have exercised & $(0.76)$ \\
& 3.4042 \\
Year fixed effects & $(3.47)^{* * *}$ \\
Observations & yes \\
Number of firms & 2,515 \\
\hline Z-Stistics in & 221 \\
\hline
\end{tabular}

z-statistics in parentheses. Constant included.

$*$ significant at $10 \%$; ${ }^{* *}$ significant at $5 \%$; $* *$ significant at $1 \%$. 
Table 8

Press data

Descriptive statistics of all articles in BusinessWeek, The New York Times, Financial Times, The Economist, and The Wall Street Journal during the 1980 to 1994 sample period that describe the sample CEOs using the terms "confident" or "confidence," "optimistic" or "optimism," or "reliable," "cautious," "practical," "conservative," "frugal," or "steady." More than one Article type and Classification source category may apply so that percentages need not add to 100. Sub-categories of Article type "About the firm" (e.g. "About a company product," etc.) give percentages out of all articles About the firm. The "CEO confident" column contains the subsample of articles describing the CEO using "confident," "confidence," "optimistic," or "optimism." The "CEO cautious" column contains the subsample of articles describing the CEO as "reliable," "cautious," "practical," "conservative," "frugal," or "steady" and any article containing negated confidence terms.

Panel A. Descriptive statistics of CEO articles

\begin{tabular}{|c|c|c|c|}
\hline & Full sample & CEO confident & CEO cautious \\
\hline Number of articles & 1,200 & 895 & 305 \\
\hline \multicolumn{4}{|l|}{ Article type } \\
\hline About the CEO & $11 \%$ & $9 \%$ & $18 \%$ \\
\hline About the firm & $80 \%$ & $83 \%$ & $72 \%$ \\
\hline About a company product & $10 \%$ & $10 \%$ & $11 \%$ \\
\hline About company earnings & $53 \%$ & $56 \%$ & $46 \%$ \\
\hline About a merger or acquisition & $17 \%$ & $15 \%$ & $22 \%$ \\
\hline About the company's culture & $6 \%$ & $5 \%$ & $12 \%$ \\
\hline Other (lawsuit, financial policy, etc.) & $16 \%$ & $17 \%$ & $12 \%$ \\
\hline About the market or industry & $13 \%$ & $12 \%$ & $16 \%$ \\
\hline \multicolumn{4}{|l|}{ Classification source } \\
\hline CEO quote & n.a. & $55 \%$ & $30 \%$ \\
\hline Journalist's assesment & n.a. & $41 \%$ & $62 \%$ \\
\hline Other assessment (colleague, business expert, etc.) & n.a. & $8 \%$ & $11 \%$ \\
\hline Reference specifies excessive confidence & n.a. & $21 \%$ & n.a. \\
\hline
\end{tabular}


Table 8 (continued)

Press data

TOTALconfident is a dummy variable equal to 1 when the number of "confident" and "optimistic" mentions for a CEO in the LexisNexis and The Wall Street Journal searches exceeds the number of "not confident," "not optimistic," and "reliable, cautious, practical, conservative, steady, frugal" mentions. TOTALmentions is the total number of articles mentioning the CEO in both sets of searches. Both dummies consider all articles over the sample period up to the previous year. Longholder is a binary variable where 1 signifies that the CEO at some point during his tenure held an option package until the last year before expiration, provided that the package was at least $40 \%$ in-the-money entering its last year. Holder 67 is a dummy equal to 1 for all CEO years after the CEO for the first time fails to exercise a $67 \%$ in-themoney option with five years remaining duration. In the Holder 67 panel, the sample is limited to CEO years after the CEO for the first time had a $67 \%$ in-the-money option with five years remaining duration. Size is the natural logarithm of assets; Q the market value of assets over the book value of assets. Cash flow is earnings before extraordinary items plus depreciation, normalized by beginning-of-the-year capital. Stock ownership is the fraction of company stock owned by the CEO and his immediate family. Vested options are the CEO's holdings of options that are exercisable within six months, as a fraction of common shares outstanding, and multiplied by ten (so that the mean is roughly comparable to Stock ownership). Efficient board size is a binary variable where 1 signifies that the board of directors has between four and 12 members. Size, Q, Stock ownership, and Vested options are measured at the beginning of the year; all other variables are at the end. Finance education is binary and equal to 1 for CEOs with an undergraduate or graduate degree in accounting, finance, business (incl. MBA), and economics. Technical education is binary and equals 1 for CEOs with an undergraduate or graduate degree in engineering, physics, operations research, chemistry, mathematics, biology, pharmacy, and other applied sciences.

Panel B. Correlations with Longholder $(N=3,328)$ and Holder $67(N=1,698)$

\begin{tabular}{rccccccc}
\hline & Longholder & TOTconf. & TOTmen. & & Holder 67 & TOTconf. & TOTmen. \\
\hline Longholder & 1 & & & Holder 67 & 1 & & \\
TOTALconfident & 0.10 & 1 & & TOTALconfident & 0.05 & 1 & 0.01 \\
TOTALmentions & 0.02 & 0.36 & 1 & TOTALmentions & -0.01 & 0.32 & 1 \\
\hline
\end{tabular}

Panel C. Correlations with firm characteristics $(N=3,328)$

\begin{tabular}{|c|c|c|c|c|c|c|c|c|}
\hline & $\begin{array}{l}\text { TOTAL- } \\
\text { confident }\end{array}$ & $\begin{array}{l}\text { TOTAL- } \\
\text { mentions }\end{array}$ & Size & $\mathrm{Q}$ & Cash flow & $\begin{array}{c}\text { Stock } \\
\text { ownership }\end{array}$ & $\begin{array}{l}\text { Vested } \\
\text { options }\end{array}$ & $\begin{array}{c}\text { Efficient board } \\
\text { size }\end{array}$ \\
\hline TOTALconfident & 1 & & & & & & & \\
\hline TOTALmentions & 0.36 & 1 & & & & & & \\
\hline Size & 0.23 & 0.32 & 1 & & & & & \\
\hline $\mathrm{Q}$ & 0.06 & 0.02 & -0.32 & 1 & & & & \\
\hline Cash flow & 0.01 & 0.05 & -0.13 & 0.39 & 1 & & & \\
\hline Stock ownership & 0.09 & 0.09 & -0.18 & 0.10 & 0.11 & 1 & & \\
\hline Vested options & 0.02 & 0.01 & -0.17 & 0.09 & 0.17 & 0.10 & 1 & \\
\hline Efficient board size & -0.07 & -0.08 & -0.38 & 0.13 & 0.06 & 0.19 & 0.08 & 1 \\
\hline
\end{tabular}

Panel D. Correlations with CEO characteristics $(N=3,293)$

\begin{tabular}{rccccc}
\hline & TOTconf. & TOTmen. & Age & Pres. \& chm. & Tenure \\
\hline TOTALconfident & 1 & & & & \\
TOTALmentions & 0.36 & 1 & & & \\
Age & 0.00 & 0.12 & 1 & & \\
President and chairman & 0.03 & 0.01 & -0.03 & 1 & \\
Tenure & 0.14 & 0.12 & 0.40 & 0.004 & 1 \\
\hline
\end{tabular}

Panel E. Correlations with CEO education $(N=2,017)$

\begin{tabular}{rcccc}
\hline & $\begin{array}{c}\text { TOTconf. } \\
\text { (lagged) }\end{array}$ & $\begin{array}{c}\text { TOTmen. } \\
\text { (lagged) }\end{array}$ & $\begin{array}{c}\text { Finance } \\
\text { education }\end{array}$ & $\begin{array}{c}\text { Technical } \\
\text { education }\end{array}$ \\
\hline TOTALconfident & 1 & & & \\
TOTALmentions & 0.36 & 1 & & \\
Finance education & 0.02 & -0.02 & 1 & \\
Technical education & 0.00 & 0.05 & -0.10 & 1 \\
\hline
\end{tabular}


Table 9

Press coverage and mergers

The dependent variable is binary where 1 signifies that the firm made at least one merger bid that was eventually successful in a given year. It is restricted to diversifying mergers in Columns (3) and (4) and to intra-industry mergers in Columns (5) and (6). Diversification is measured using the Fama-French 48 industries. Size is the log of assets, Q the market value of assets over the book value of assets. Cash flow is earnings before extraordinary items plus depreciation, normalized by beginning-of-the-year capital. Stock ownership is the fraction of company stock owned by the CEO and his immediate family. Vested options are the CEO's holdings of options that are exercisable within six months, as a fraction of common shares outstanding, and multiplied by ten (so that the mean is roughly comparable to Stock ownership). Efficient board size is a binary variable where 1 signifies that the board of directors has between four and 12 members. CEO age is measured in years. CEO chairman \& president is a dummy variable and equal to 1 if the CEO is also chairman of the board and president of his company. Finance education is binary and equal to 1 for CEOs with undergraduate or graduate degrees in accounting, finance, business (incl. MBA), or economics. Technical education is binary and equals 1 for CEOs with undergraduate or graduate degrees in engineering, physics, operations research, chemistry, mathematics, biology, pharmacy, or other applied sciences. Size, Q, Stock ownership, and Vested options are measured at the beginning of the year; all other variables are at the end. TOTALconfident is a dummy variable equal to 1 when the number of "confident" and "optimistic" mentions for a CEO in the LexisNexis and The Wall Street Journal searches exceeds the number of "not confident," "not optimistic," and "reliable, cautious, practical, conservative, steady, frugal" mentions. TOTALmentions is the total number of articles mentioning the CEO in both sets of searches. Both dummies consider all articles over the sample period up to the previous year. The "No past merger" state dummies capture time in the initial state and run from "Second year as CEO" to "Fourteenth year as CEO." The sample is restricted to all firm years up to the first merger for a given CEO (and drops all firm years under that CEO after the first merger, if any). It is also restricted to CEOs whose tenure begins between 1980-1994 so that press coverage is all-inclusive. Standard errors are robust to heteroskedasticity and arbitrary within-firm serial correlation. Coefficients are presented as odds ratios.

\begin{tabular}{|c|c|c|c|c|c|c|}
\hline & \multicolumn{2}{|c|}{ All mergers } & \multicolumn{2}{|c|}{ Diversifying mergers } & \multicolumn{2}{|c|}{ Intra-industry mergers } \\
\hline & $(1)$ & (2) & (3) & (4) & (5) & (6) \\
\hline \multirow[t]{2}{*}{ Size } & 0.8919 & 0.8580 & 0.9411 & 0.813 & 0.7757 & 0.8897 \\
\hline & $(1.03)$ & $(0.97)$ & $(0.41)$ & $(0.93)$ & $(1.72)^{*}$ & $(0.52)$ \\
\hline \multirow[t]{2}{*}{ Q } & 0.5967 & 0.6876 & 0.6963 & 0.7351 & 0.3837 & 0.523 \\
\hline & $(2.19)^{* *}$ & $(1.18)$ & $(1.23)$ & $(0.67)$ & $(2.67)^{* * *}$ & $(1.66)^{*}$ \\
\hline \multirow[t]{2}{*}{ Cash flow } & 1.7996 & 1.5027 & 1.7200 & 1.0514 & 2.2824 & 3.0977 \\
\hline & $(2.28)^{* *}$ & $(1.17)$ & $(1.75)^{*}$ & $(0.11)$ & $(2.28)^{* *}$ & $(2.27)^{* *}$ \\
\hline \multirow[t]{2}{*}{ Stock ownership } & 2.2172 & 0.6546 & 4.4640 & 1.3446 & 0.6097 & 0.0589 \\
\hline & $(0.65)$ & $(0.28)$ & $(1.05)$ & $(0.17)$ & $(0.29)$ & $(0.78)$ \\
\hline \multirow[t]{2}{*}{ Vested options } & 7.0257 & 130.212 & 27.5615 & $7,409.64$ & 0.1693 & 0.0008 \\
\hline & $(0.95)$ & $(0.93)$ & $(0.72)$ & $(1.76)^{*}$ & $(0.42)$ & $(0.65)$ \\
\hline \multirow[t]{2}{*}{ Efficient board size } & 0.8396 & 0.7450 & 0.8600 & 0.7204 & 0.8038 & 0.7434 \\
\hline & $(0.78)$ & $(0.95)$ & $(0.50)$ & $(0.82)$ & $(0.75)$ & $(0.76)$ \\
\hline \multirow[t]{2}{*}{ CEO age } & & 1.0047 & & 1.0036 & & 1.0156 \\
\hline & & $(0.18)$ & & $(0.12)$ & & $(0.32)$ \\
\hline \multirow[t]{2}{*}{ CEO chairman and president } & & 0.9431 & & 0.7984 & & 1.2737 \\
\hline & & $(0.21)$ & & $(0.68)$ & & $(0.57)$ \\
\hline \multirow[t]{2}{*}{ Finance education } & & 1.5721 & & 1.9397 & & 1.1161 \\
\hline & & $(1.62)$ & & $(1.98)^{* *}$ & & $(0.24)$ \\
\hline \multirow[t]{2}{*}{ Technical education } & & 0.9185 & & 0.9385 & & 1.0711 \\
\hline & & $(0.31)$ & & $(0.19)$ & & $(0.15)$ \\
\hline \multirow[t]{2}{*}{ TOTALmentions } & 1.0009 & 1.0003 & 1.0019 & 1.0028 & 0.9985 & 0.9946 \\
\hline & $(0.37)$ & $(0.09)$ & $(0.70)$ & $(0.88)$ & $(0.39)$ & $(0.95)$ \\
\hline \multirow[t]{2}{*}{ TOTALconfident } & 1.7972 & 2.5442 & 2.1734 & 3.2492 & 1.4250 & 1.6670 \\
\hline & $(1.74)^{*}$ & $(2.36)^{* *}$ & $(1.83)^{*}$ & $(2.35)^{* *}$ & $(0.75)$ & $(0.86)$ \\
\hline "No past merger" state dummies & yes & yes & yes & yes & yes & yes \\
\hline Year fixed effects & yes & yes & yes & yes & yes & yes \\
\hline Observations & 1,144 & 716 & 1,144 & 716 & 1,040 & 548 \\
\hline
\end{tabular}

z-statistics in parentheses. Constant excluded.

* significant at $10 \%$; ** significant at $5 \%$; *** significant at $1 \%$. 